Revta bras. Zool., 6(2):325-375 15/VIII/1989

\title{
Revisão das espécies e posição sistemática de Palpibracus Rondani (Diptera, Muscidae) $^{1}$
}

\author{
Claudio José Barros de Carvalho
}

\begin{abstract}
A systematic revision of the species of Palpibracus Rondani, 1864 from South America is presented. This genus was formerly placed in Phaoniini but through the study of the chaetotaxy and the new characters or with reinterpretation of those already known, is here proposed its transferrence to Azeliinae, Reinwardtiini. Some remarks on this new systematic position are analysed.

The following species are redescribed: P. apicalis, P.chilensis, P. confusus, P. fasciculatus, P. lancifer, P. nigriventris, P. pilosus, P. reynoldsi, P. separatus, P. similis, P. spicatus, P. trivittatus, P. univittatus and $\mathbf{P}$. veneris.

Palpibracus albuquerquei $s p$. n., from Angol, Chile, is described. A new combination for Phaonia peruviana Malloch, 1929 is proposed - Palpibracus peruvianus nov. comb. - and Darwinomyia angolensis Malloch, 1934 is considered as a new synonym.

A key and maps of geographical distribution of the species are given.

O conhecimento dos Muscidae neotropicais carece de compreensão, tanto a nível específico quanto a nível de relacionamento intergenérico. Muitos táxons são conhecidos apenas de suas descrições originais e, por isso, os caracteres importantes para o entendimento dos Muscidae não foram devidamente avaliados, dentro do escopo global da familia.

O objetivo principal deste trabalho é a revisão de Palpibracus Rondani que possui uma distribuição peculiar, restrita ao Sul da América do Sul.
\end{abstract}

\section{MATERIAL E MËTODOS}

Foi estudado material proveniente das instituições listadas abaixo; entre parênteses os curadores ou responsáveis pelo empréstimo dos exemplares. 
BMNH - Department of Entomology, British Museum (Natural History), Cromwell Road, London, SW7 5BD, (Mr. A. C. Pont).

$\mathrm{CNC}$ - Biosystematics Research Institute, Canadian National collection, Otawa, Ontario, K1A OC6, Canada (Dr. J. R. Vockeroth).

DZUP - Museu Pe . Jesus S. Moure, Departamento de Zoologia, Universidade Federal do Paraná, Caixa Postal 3034, CEP 80001, Curitiba, Paraná, Brasil. IML - Fundación Miguel Lillo, Instituto de Zoologia Miguel Lillo, 205, 4000, San Miguel de Tucumán, Argentina (Dr. A. Willink).

MNRJ - Museu Nacional, Universidade Federal do Rio de Janeiro, Quinta da Boa Vista, CEP 20942, Rio de Janeiro, Brasil (Prof. S. M. Lopes).

MZSP - Museu de Zoologia, Universidade de São Paulo, Av. Nazareth 481,

Caixa Postal 7172, CEP 01051, São Paulo, Brasil (Dr. J. H. Guimarães).

USNM - Systematic Entomology Laboratory, U. S. Department of Agriculture

c/o USNM, NHB 168, Washington, D. C. 20560, Estados Unidos (Dr. R. J. Gagné).

WSUP - Department os Entomology, James Entomological Collection,

Washington State University, Pullmann, W. A. 99164 - 6432, Estados Unidos (Dr. R. S. Zack).

Foram dissecadas as probóscides das espécies, um exemplar fêmea por espécie, exceto para Palpibracus albuquerquei, P. peruvianus e P. similis, pois havia escasso material. As cabeças foram seccionadas e colocadas em uma solução de Hidróxido de Potássio, à frio, por tempo variável, entre 18-36 horas. Depois, foram lavadas em álcool 70\%, dissecadas e desenhadas em glicerina não hidratada. Após a análise do material, a cabeça foi colada no exemplar de origem e a probóscide dissecada, acondicionada em um tubinho de vidro (5 x $13 \mathrm{~mm}$ ), com pouca glicerina no fundo, fixado ao alfinete.

Nas descrições e redescrições do gênero ou das espécies, os caracteres utilizados foram retirados dos trabalhos habitualmente feitos com Muscidae, porém, tendo como base os trabalhos de CARVALHO (1983, 1984, 1985a), com pequenas modificações. A terminologia utilizada foi basicamente do trabatho de McALPINE (1981). Para alguns têrmos, entretanto, pela conceituação não muito clara no trabalho citado (vide O'HARA, 1982, para alguns pontos de discussão), foram mantidos os têrmos tradicionalmente utilizados na taxonomia da famılia. Assim, foram utilizados têrmos como, cerdas umerais, cerda pós-umeral, cerda pré-sutural (intra-alar pré-sutural), cerda pré-alar (primeira supralar pós-sutural) e calcar (cerda na tíbia III, face posterodorsal).

Para a terminologia da probóscide utilizaram-se os trabalhos de MATSUDA (1965) e McALPINE (1981).

$\mathrm{Na}$ descrição de certos caracteres, foram utilizados alguns têrmos específico, ausentes na língua portuguesa. São eles:

Esclerotinizado - enrijecimento de áreas do tegumento através da formação de esclerotina;

Polinosidade - revestimento do tegumento, com aspecto de pó, de coloração cinzento-prateada;

Foram utilizadas abreviaturas para alguns nomes de cerdas (em negrito) a posições (em caixa alta). As abreviaturas seguem, com pequenas exceções, o tra- 
Vol. 6(2), 1989

balho de Pont (1973):

A - face anterior; acr - cerdas acrosticais; AD - face anterodorsal; AV face anteroventral; ctpl - cerdas catepisternais; D - face dorsal; dc - cerda dorsocentral; ia - cerda intralar; $\mathrm{npl}$ - cerda notopleural; $\mathrm{P}$ - face posterior; PD - face posterodorsal; PV - face posteroventral; pra - cerda pré-alar; prs cerda pré-sutural; psa - cerda pós-supralar; $\mathbf{s a}$ - cerda supralar ; V - face ventral; vte - cerda vertical externa; vti - cerda vertical interna.

Após a citação do autor, ano e página do trabalho, foi colocada entre parênteses uma abreviatura salientando o tema a que o trabalho se refere. Foram elas: biol. $=$ dados biológicos; cat. $=$ catálogo; cit.$=$ citação; desc.$=$ descrição; rdesc $=$ redescrição; pcat. $=$ catálogo parcial.

Com a mesma finalidade, foram colocadas também algumas palavras não abreviadas como, chave, macho e fêmea.

Os dados de etiquetas dos holótipos, alótipos e parátipos examinados, foram apresentados de maneira uniforme. Este estilo foi primeiramente utilizado por ARNAUD (1979), mas foi melhor caracterizado por O'HARA (1982). Foi também incluída a localização da deposição do holótipo, quando conhecida, e o estado de conservação dos tipos estudados. Este estilo foi utilizado por LOPES et alii (no prelo).

\section{Palpibracus Rondani}

Brachypalpus Macquart, 1851: 260 (desc. Preoc. Diptera, Syrphidae); Seguy, 1937:318 (cat., rdesc. fêmea). Espécie-tipo: Brachypalpus pilosus Macquart, 1851 (des. orig.).

Palpibracus Rondani, 1864: 35 (nom. nov. para Brachypalpus Macquart, 1851); Albuquerque, 1951:6 (partim, cit.); Hennig, 1965: 41 (cit.); Pont, 1972:16 (cat.). Espécie-tipo: Brachypalpus pilosus Macquart, 1851 (aut.).

Darwinomyia Malloch, 1922: 277 (desc.); Malloch, 1928: 313 (cit., chave); Malloch, 1934: 316 (desc., chave); Snyder, 1957: 488 (cit.); Dodge, 1967: 243 (cit.). Espécie-tipo: Darwinomyia univittata Malloch, 1922 (des. orig.) $=\mathrm{D}$. confusa Malloch, 1928 .

Acrolasia Enderlein, 1927:54 (desc.); Malloch, 1928: 313 (cit); Malloch, 1934: 317 (cit.). Espécie-tipo: Yetodesia chilensis Bigot, 1885 (des. orig.).

Anacanthosphys Enderlein, 1935: 243 (desc.). Espécie-tipo: Darwinomyia trivittata Malloch, 1934 (des. orig.).

Acanthosphys Enderlein, 1935: 244 (desc.). Espécie-tipo: Darwinomya reynoldsi Malloch, 1934 (des. orig.).

Catantingymnus Enderlein, 1935: 244 (desc.). Espécie-tipo: Helomyza veneris Bigot, 1888 (des. orig.).

Reconhecimento: olhos ciliados; holóptico; arista pubescente com os cílios menores que a largura da arista na base; antena com o terceiro artículo fracamente dilatado ou não; acr pré-suturais desenvolvidas; pra forte; notopleura nua; 
segunda np1 pequena; espiráculo anterior reniforme; catepimero ciliado ou nu; uma cerda pro-epimeral; as com as veias nuas; tíbia II na face PV geralmente com uma cerda mediana ou mais; tíbia III na face PD com o calcar seguido ou não de mais cerdas; abdome ovalado, curto, menor que o comprimento do tórax; 1. Esternito nu. Macho: espiráculo posterior de tamanho médio, ovalado a desenvolvido, quadrangular; coxa I geralmente com forte esporão apical. Fêmea: vte e vti semelhantes entre si; cerdas interfrontais presentes ou ausentes; clípeo, em vista lateral, na região anterior com um forte ponta; haustelo, na região anterior, com esclerotinização ciliada (figs. 61-72); ovipositor longo, tubular, cerca de 1.5 vezes o comprimento do abdome; tergito VI esclerotinizado em forma de âncora; tergito VII geralmente estreito, em posição médio-lateral, exce to em P. veneris; esternito VI e VII divididos posteriormente, exceto em $\mathbf{P}$. lancifer; microtríquias geralmente ausente a fracamente desenvolvidas, exceto em P. apicalis; esternito VIII desenvolvido em toda sua extensão, mais esclerotinizado na região posterior, exceto em P. apicalis; hipoprocto alongado, mais longo que largo; três espermatecas piriformes (figs. 1-3; 13-15; 25-27; 37-39; 49-51).

Considerações: como na maioria dos Muscidae, também em Palpibracus Rondani, as estruturas e a quetotaxia das fêmeas são bastante reduzidas, em se comparando com os machos; existe uma simplificação de caracteres e as identificações são mais difíceis. Procurou-se, na medida do possível, na confecção da chave, agrupar machos e fêmeas nas dicotomias (cf MALLOCH, 1934), para facilitar o agrupamento dos sexos.

Este gênero é bastante peculiar; sua coloração é extremamente variável e a quetotaxia é raramente simétrica.

Afinidades: Autores precedentes não tinham idéia clara do relacionamento deste gênero. MALLOCH (1934:316) dizia: "I am averse to sinking the group as merely a subgenus of Phaonia as there is no doubt in my mind it is an endemic group that may have been derived from entirely different stock from that which produced Phaonia in Europe". Entretanto, no mesmo trabalho, comentava (MALLOCH, 1934:314): "There can be no objection to the acceptance of the theory that all three (Palpibracus, Brachygasterina e Psilochaeta) are offshoots from Phaonia, and if not acceptable as genera then they are undoubtedly at least entitled to subgeneric segregation ...". HENNING (1965:41) também não se posiocionou claramente. Autores contemporâneos (A. C. PONT, in litt, 19 XII. 1986) afirmou: "My feelings (not based on any analysis) is that Palpibracus is a good genus, perhaps a tertiary relic from early Phaoniinae stock, whereas Psilochaeta, Brachygasterina, Correntosia and Euphaonia are all species-groups (or just 1-2 species-groups) within Phaonia".

A subfamilia Phaoniinae como compreendida atualmente é parafilética (HENNIG, 1965; vide também CARVALHO, 1985b; COURI \& LOPES, 1985), enquanto que Phaonia R.-D., 1830, é um agregado de gêneros distintos que necessita ser redefinido a nível mundial (vide SKIDMORE, 1985; HUCKETT \& VOCKEROTH, 1987). Na região neotropical a verdadeira Phaonia deve estar restrita somente ao grupo de espécies que formavam os antigos Bigotomyia Malloch, agora subgrupo de Phaonia s.str. (vide ZINOVJEV, 1981; SKIDMORE, 
1985). Os Phaonia (aut.) neotropicais é um grupo bem mais basal, com caracteres, principalmente o ovipositor, mais primitivos (e. g. membranas e escleritos recobertos de microtríquias). CARVALHO (no prelo) apresenta uma classificação da famılia baseada na Análise cladística.

Indubitavelmente Palpibracus Rondani não é um Phaoniinae. Caracteres de morfologia externa colocam-no em Azeliinae, Reinwardtiini, especialmente os de ovipositor. Esta tribo está incluída nos Azeliinae através de um caráter seguramente derivado nos Muscidae: tergito VI esclerotinizado em forma de âncora. O plano básico dos Muscidae apresenta os escleritos do ovipositor largos e desenvolvidos (cf. Achanthiptera Rondani) (HENNIG, 1965). A monofilia de Reiwardtiini (Reinwardtiinae sensu Skidmore, 1985) ainda não está fundamentada, com os gêneros reunidos principalmente através de caracteres primitivos.

Em Palpibracus, entre as espécies conhecidas, P. apicalis está em uma posição isolada das demais, por possuir caracteres mais plesiomórficos dentro do gênero.

Distribuição geográfica: o gênero possui distribuição bem restrita, com ocorrência somente no Chile e Argentina, em regiões andinas, ao sul do paralelo $30^{\circ}$.S. Salvo melhor cobertura geográfica, são observados três padrões de distribuição das espécies. P. fasciculatus, P. nigriventris e P. veneris ocorrendo em toda a região. A maioria das espécies, entretanto, apresenta uma área de distribuição mais ao norte. São elas: P. albuquerquei, sp. n., P. apicalis, P. chilensis, P. confusus, P. lancifer, P. peruvianus, P. separatus, P. similis, P. spicatus, P. trivittatus e P. univittatus. Apenas duas espécies, P. pilosus e P. reynoldsi, ocorrem no extremo sul do continente. 1934).

Chave para as espécie de Palpibracus Rondani (modificada de MALLOCH,

1. Catepimero com cilios na margem superior em frente ao espíraculo posterior, usualmente pretos, raramente amarelos . . . . . . . . . . . 2

- Catepimero nu . . . . . . . . . . . . . . . . . 8

2. Antena e palpo, no mínimo, em parte amarelos; tíbia II na face PV com uma ou mais cerdas. Macho: cabeça normal, com a largura menor que a altura; olhos com as facetas anterointernas pouco desenvolvidas: cerdas frontais em toda a fronte, as superiores mais fracas . . . . . . . . . . . 3

- Antena e palpo castanho-escuros; tíbia II na face PV nua. Macho: cabeça larga, com a largura igual a altura; olhos com as facetas anterointernas grandemente desenvolvidas; cerdas frontais limitadas à metade anterior. CHILE (Nuble, Llanquilhue, Chiloe, Magallanes); ARGENTINA (Rio Negro, Terra do Fogo) . . . . . . . . . . . . . . . . P. veneris (Bigot)

3. Macho: coxa I com forte esporão apical; Tíbia I na face AV com 2-3 cerdas no terço apical; tíbia III na face PV nua, com cîlios na metade basal ou apical, nunca em toda a face. Fêmea: cerdas interfrontais

cruzadas presentes: tíbia II na face PV com 1-3 cerdas submedianas ............................ 4 
- Macho: coxa I inerme, no máximo com cerdas apicais, tíbia I na face AV com uma cerda no terço apical; tíbia III na face PV com séries de c1lios longos uniformes em toda a face. Fêmea: cerdas interfrontais ausentes; tíbia II na face PV com apenas uma cerda submediana. CHILE (Santiago, Linares, Concepcion, Osorno) ..... . . . P. separatus (Malloch)

4. Macho: parafaciália ao nível do ápice do segundo artículo antenal cerca de $2 / 3$ menor que a largura da gena ao nível inferior do olho; fêmur II côncavo, face $\mathrm{A}$ com uma forte ou leve depressão mediana. Fêmea: vita frontal castanho-escura a castanho-escura com a metade anterior avermelhada; tibia I na face AV com apenas uma cerda submediana . . . . . . 5

- Macho: parafaciália larga, ao nível do ápice do segundo artículo antenal, semelhante à largura da gena ao nível inferior do olho; fêmur II normal, sem depressão na face A. Fêmea: vita frontal totalmente avermelhada; tíbia I na face $\mathrm{AV}$ com 1-2 cerdas no terço apical. CHILE (Magallanes); ARGENTINA (Santa Cruz, Terra do Fogo)

\section{P. reynoldsi (Malloch)}

5. Coxa I amarela ou no máximo negra na metade apical. Macho: cerdas frontais em número máximo de nove pares; fêmur II na face $\mathrm{A}$ com 1-2 séries de espinhos curtos e fortes no ápice; tibia III na face PD com 3-4 cerdas, o calcar inserido no terço apical. Fêmea: vita frontal em parte avermelhada

- Coxa I inteiramente negra. Macho: cerdas frontais em número de 10-11 pares; fêmur II na face A sem espinhos curtos no ápice; tíbia III na face PD com cinco cerdas em toda a face, o calcar inserido submedianamente. Fêmea: vita frontal castanho-escura. CHILE (Nuble); ARGENTINA (Neuguén, Rio Negro) . . . . . . . . . . . . . . . . . P. similis (Malloch)

6. Macho: fêmures II e III em parte castanho-escuros; fêmur II na depressão mediana, com pélos de revestimento normais. Fêmea: fêmur III amarelo com cerca de 2/3 negros; tíbia III na face AV com uma série de 5-6 cerdas na metade apical; face PD com 2-3 cerdas no terço médio . . . . . . . 7

- Macho: fêmures II e III amarelados; fêmur II na depressão mediana sem pêlos de revestimento. Fêmea: fêmur III amarelo com apenas um anel pré-apical negro; tíbia III na face AV com uma série de $4-5$ cerdas na metade apical; face PD com duas cerdas no terço médio. CHILE (Curicó, Malleco) . . . . . . . . . . . . . . . . . . . P. chilensis (Bigot)

7. Macho: Tíbia I na face AV com duas cerdas na metade apical; face V com 3-4 cerdas filiformes no terço apical; face PD de zero à duas cerdas no quinto apical; fêmur III amarelo com $2 / 3$ apicais negros; Tíbia III negra; face AV com uma série de cerdas filiformes em toda a face, maiores para o ápice; face PV com apenas pélos no terço apical; face PD com 3-5 cerdas em toda a face. Fêmea: tíbia I na face PD com 3-4 cerdas pequenas em toda face; tíbia II na face PV com 1-3 cerdas na metade apical. CHILE (Curico, Nuble, Malleco, Chiloé); ARGENTINA (Chubut, Santa Cruz) . . . P. confusus (Malloch)

- Macho: tíbia I na face AV com uma série de cerdas fracas na metade apical; face PD com uma cerda mediana; fêmur III amarelo com um anel no 
terço médio negro; tíbia III amareláda; face AV com uma série de pequenas cerdas em toda a face; face PV e V com pelos na metade apical, maiores e mais densos para o ápice; face PD com trếs cerdas no terço médio. Fêmea: desconhecida . . . . . . . . . . . P. pilosus (Macquart)

8. Coloração azul-metálica com o abdome, no máximo, apresentando parte do tergito $\mathrm{V}$ amarelo-vivo . . . . . . . . . . . . . . . . . 9

- Coloração amarela a negra, no mínimo parte do tórax amarelo; abdome nunca azul-metálico . . . . . . . . . . . . . . . . . . . . 10

9. Olhos longa e conspicuamente ciliados; pernas negras com os tarsos em parte branco-amarelado, mais evidente nas pernas anteriores dos machos; abdome azul-violáceo metálico, com a metade apical do tergito $\mathrm{V}$ amarelovivo. Macho: coxa I sem esporão apical; cerdas frontais em número de 12-16 pares; tíbia I na face A e AV com pélos cerdiformes longos em toda a face; tíbia II na face P com 4-5 cerdas de aspecto normal nos 2/3 basais. Fêmea: tíbia I na face PD nua; fêmur II na face PV com uma série de cerdas na metade basal. CHILE (Osorno, Llanquihue); ARGENTINA (Rio Negro) . . . . . . . . . . . . . . . . . . P. apicalis (Malloch)

- Olhos curta e esparsamente ciliados; pernas amarelas com as coxas, trocânteres e tarsos negros; abdome azul-violáceo metálico. Macho: coxa I com forte esporão apical; cerdas frontais em número de oito pares; tibia I na face P com cerdas longas e fortes em toda a face. Fêmea: tỉbia I na face PD com duas cerdas pequenas no limite do terço apical; fêmur II na face PV com uma cerdas forte isolada no terço basal. CHILE (Osorno), ARGENTINA (Rio Negro)

P. lancifer (Malloch)

10. Macho: tórax amarelo com uma listra negra mediana; coxa I com forte esporão apical: Fêmea: cerdas interfrontais presentes ou ausentes; tíbia III na face AV com $3-5$ cerdas na metade apical ... . . . . . . . . . 11

- Macho: tórax amarelo com uma listra negra mediana ou negro com listras polinosas cinzentas; coxa I inerme. Fêmea: cerdas interfrontais presentes; tibia III na face $A V$ com $2-3$ cerdas na metade apical . . . . . . . . . . 13

11. Antena castanho-escura com o segundo artículo pouco mais claro; palpo castanho-escuro. Macho: tíbia III encurvada ou não; face AV com uma série de cerdas longas, maiores que a largura da tíbia, em toda a face; face PV com uma série de cerdas longas e finas nos 2/3 apicais. Fêmea: Vita frontal castanho-escura, avermelhada ou não no centro . . . . . . . . . 12

- Antena castanho-escura com o primeiro, segundo e base do terceiro artículo amarelos. Macho: tíbia III com uma curvatura; face AV com uma série de cerdas curtas, menores que a largura da tíbia, em toda a face; face PV com uma série de cílios em toda a face, maiores no quinto apical. Fêmea: vita frontal amarelada, levemente escurecida posteriormente. CHILE (Osorno, Chiloé) . . . . . . . . . . . . P. univittatus (Bigot)

12. Gena amarelo-alaranjada; tórax amarelo com uma listra torácica mediana, estreita, coincidindo com as acr. Macho: tíbia II na face PD com 24 cerdas em toda a face; tíbia III normal. Fêmea: cerdas interfrontais ausentes. CHILE (Curicó, Osorno, Chiloé); ARGENTINA (Rio Negro ) . . . . . . . . . 
- Gena castanho-escura; tórax amarelo com uma listra torácica, mediana, larga, coincidindo com as acr. Macho: tíbia II na face PD com 4-6 cerdas em toda a face; tíbia III curva. Fêmea: cerdas interfrontais presentes. CHILE (Malleco, Cautin) . . . . . . . . . . . P. albuquerquei sp.n.

13. Palpo castanho-escuro; tórax amarelo com uma a três listras isoladas ou fundidas. Macho: antena inserida abaixo da metade do olho. Fêmea: abdome castanho-escuro . . . . . . . . . . . . . . . 14

- Palpo amarelado com base castanha; tórax negro, com três listras polinosas cinzentas e poucas áreas amarelas. Macho: antena inserida acima da metade do olho. Fêmea: abdome amarelo-opaco. CHILE (Curicó, Bio Bio, Malleco) . . . . . . . . . . . . . P. peruvianus (Malloch) comb.n.

14. Macho: facetas anterointernas alargadas; tíbia na face AV com 2-3 cerdas no terço apical; face V com 1-4 cílios longos no terço apical; face PV com 2-3 no terço médio. Fêmea: vita frontal avermelhada em quase toda exten-

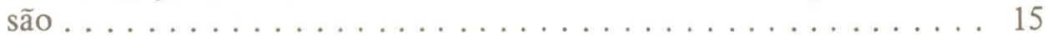

- Macho: facetas anterointernas grandemente alargadas; tíbia I na face AV com uma cerda no terço médio; face V sem c1lios; face PV com 1-2 cerdas no terço médio. Fêmea: vita frontal castanho-escura com apenas a metade anterior levemente avermelhada. CHILE (Curicó, Malleco, Cautin, Llanquihue; Chiloé, Magallanes); ARGENTINA (Neuquén, Rio Negro, Santa Cruz) . . . . . . . . . . . . . . . P. nigriventris (Malloch)

15. Tórax amarelo com listra negra, larga, coincidindo com as dc; fêmeas não raramente com listra estreita. Macho: tíbia I na face V com quatro cilios longos no terço apical; tíbia III curva, face PV com uma série de cílios finos no terço médio que se alongam formando um conspícuo pincel. Fêmea: tíbia II na face V com uma cerda, distinta submediana; fêmur III fortemente curvo e levemente intumescido pré-apicalmente. CHILE (Chiloe ); ARGENTINA (Rio Negro, Santa Cruz) . . P. fasciculatus (Malloch)

- Tórax amarelo com três listras negras, separadas ou fundidas. Macho: tíbia I na face V com 1-2 c1lios longos medianos; tíbia III normal; face PV com série de culios fortes, ausentes no terço apical. Fêmea: tíbia II na face V sem cerdas; fêmur III levemente curvo. CHILE (Linares, Malleco); ARGENTINA (Rio Negro) . . . . . . . . . . . . . P. trivittatus (Malloch)

\section{Palpibracus albuquerquei $s p . n$.}

(Figs. 1, 4-6, 73)

Material-tipo: Holótipo -macho, etiquetado: "Angol-Chile/16.Oct.1928 (16.X. 1928)"; "Holotipo" (etiqueta vermelha, com uma linha preta no bordo)"; "Papibracus/sp. n. (etiqueta manuscrita de Albuquerque)". Está em razoável estado; faltam pernas anteriores; perna mediana esquerda colada na etiqueta de procedência; quetotaxia quase completa; o abdome está dissecado, acondicionado em tubinho com glicerina.

Alótipo.-fêmea, etiquetado: "Termas Rio Branco/Cura Cautin. Chile/28 Marzo 1938 (28.III.1938)"; ALOTIPO (etiqueta rosa, com uma linha preta no 
bordo)"; Está em razoável estado: tegumento um pouco sujo; faltam pernas anterior direita e mediana esquerda; asa direita montada em microlâmina com Bálsamo do Canadá.

Reconhecimento: coloração geral amarela com uma listra torácica negra, larga mediana. Macho: tỉbia II na face PD com 4-6 cerdas em toda face.

Coloração: coloração geral amarela com discreta polinosidade cinzenta, apresentando no tórax uma listra negra, mediana. Parafrontália, faciália, parafaciália e gena castanho-escuras com polinosidade cinzenta. Lúnula amarela com polinosidade cinzenta. Fêmea com vita frontal negra-aveludada, levemente avermelhada anteriormente. Palpo castanho-escuro. Antena castanho-escura com o ápice do segundo artículo pouco mais claro; arista castanho-escura com anel pré-basal amarelado. Tórax amarelo com uma listra negra, mediana, que ao nǐvel do primeiro par de acr pré-sutural se alarga até o nivel das de e atinge o escutelo. Escutelo amareloclaro. Pleuras inferiores, anepimero, catepisterno, meron e pós-noto negros. Caliptras e balancim amarelados. Asa amarelada com as veias castanho-claras. Pernas castanho-escuras com tibias poucos mais claras; pulvilos amarelos. Abdome negro com discreta polinosidade cinzenta.

Descrição.-Macho: $6.75 \mathrm{~mm}$. Asa: $7.50 \mathrm{~mm}$.

Cabeça: olhos fortemente unidos, com esparsos cilios curtos, afastados por um espaço que mede à altura do ocelo anterior $0.20 \mathrm{~mm}$; facetas anterointernas poucos desenvolvidas. Cerdas frontais em número de oito pares, iniciados ao nivel da lúnula e terminados abaixo do ocelo anterior, os superiores mais fracos. Vti proclinadas, poucos menores que as vte, que são divergentes. Antena inserida abaixo da metade do olho, com o terceiro artículo medindo cerda de 1.8 vezes o segundo. Parafácialia larga, ao nivel do ápice do segundo artǐculo antenal cerca de $2 / 3$ da largura da gena ao nivel inferior do olho. Palpo falciforme com pélos longos.

Tórax: de 2:4, acr 2:3; duas cerdas umerais; uma pós-umeral; uma prs; duas ia; pra forte, pouco maior que a npl anterior; duas sa, a posterior cerca da metade da anterior; duas psa, a posterior mais forte. Notopleura com duas cerdas, a posterior cerca da metade da anterior e sem cilios de revestimento. Escutelo com um par de cerdas basais fracas: dois laterais fortes, o anterior semelhante ao apical; um, pré-apical fraco e um apical robusto. Anespisterno com uma série de seis cerdas e vários cillios. Uma cerda pro-episternal e duas pro-epimerais. Ctps 1:2, a posterior maior. Catepimero nu. Espiráculo posterior médio, ovalóide. Caliptra inferior medindo cerca de 1.4 a superior. Asa com as veias $\mathrm{R} 4+5$ e M 1+2 divergentes para o ápice. Coxa I com forte esporão apical. Fêmur II nas faces PD com duas cerdas pré-apicais e P com uma, inseridas obliquamente ao plano longitudial do fêmur; face PV com uma forte cerda no terço basal e seis mais fracas no quarto apical. Tibia na face PV com uma forte cerda no terço basal e seis mais fracas no quarto apical. Tibia na face PV com 4-6 cerdas em toda a face; face PV com uma cerda no terço médio. Tarso sem pêlos sensitivos longos; unhas e pulvilos curtos, menores que o comprimento do pré-tarso. Fêmur III levemente curvo e levemente intumescido pré-apicalmente; face AV com três cerdas, duas mais fortes no quinto apical; face AD com uma série de cerdas a partir do terço apical; face D com duas cerdas no terço apical; face PD com duas pequenas cerdas pré-apicais inseridas obliquamente. Tibia 
curva; face $\mathrm{AD}$ com duas cerdas filiformes na metade apical, a mediana mais forte; face AV com série de cerdas em toda a face, maiores e duplas na metade apical; face P com uma série de cerdas em toda a face, maiores na metade apical; face PD com o calcar forte, inserido no quarto apical. Tarso como no par mediano.

Genitália: (foi dissecado o holótipo) cercos, epândrio e surstilos (figs. 4 e 5); quinto esternito (fig. 6).

Fêmea: $6.92 \mathrm{~mm}$. Asa: $7.25 \mathrm{~mm}$.

Semelhante ao macho, diferindo no que segue: olhos quase nus, separados por um espaço de cerca de 0.37 da largura da cabeça, ao nivel da lúnula; vita frontal com cerdas intercruzadas e inseridas ao nivel da metade; triângulo ocelar longo, cerca da metade da vita frontal; cerdas frontais em número de sete cerdas, os dois superiores reclinados; vte e vti semelhantes entre si; antenas inseridas acima da metade do olho; fêmur I nas face AD e AV com uma série de cerdas fortes em toda a face; face A com série de cerdas fracas; tíbia na face AV com uma cerda submediana; face PD com uma cerda pequena no quinto apical; fêmur III levemente curvo; tibia na face AD com duas cerdas na metade apical; face AV com três cerdas no terço médio.

Ovipositor: (foi dissecado o alótipo) ovipositor longo, tubular, cerca de 1.5 vezes maior que o comprimento do abdome; sem microtrĭquias; tergito VII estreito (fig. 1).

Afinidades: próxima a $P$. spicatus diferindo pelos caracteres de chave: coloração da gena, largura da listra torácica mediana central; ciliação da tỉbia II e curvatura da tỉbia III nos machos; fêmeas com cerdas interfrontais cruzadas.

Distribuição geográfica (fig. 73): CHILE (Malleco, Cautin).

\section{Palpibracus apicalis (Malloch)}

(Figs. 2,7-9, 61, 74)

Darwinomyia apicalis Malloch, 1934: 328 (desc. macho/fêmea). Palpibracus apicalis; Pont, 1972: 17 (cat.).

Material-tipo: o holótipo macho não foi examinado e provavelmente está depositado no "British Museum Natural History" (MALLOCH, 1934).

Seis parátipos machos, etiquetados: "Casa Pangue/Llanquihue/ChileDec 1926 (Chile, XII.1926)/R \& EShannon"; "Paratype No/49768/U. S. N. M. (etiqueta vermelha)"; "Darwinomyia/apicalis/Paratype/det. J. R. Malloch (etiqueta manuscrita de Malloch)" (USNM, MNRJ). Estão em estado razoável. Faltam pernas, cerdas e algumas asas estão danificadas.

Um parátipo macho, etiquetado: "Bariloche/Rio Negro/Agr-Nov1926 (Argentina, xi.1926)/R \& Shannon"; "Paratype No/49768/U. S. N. M. (etiqueta vermelha)" (USNM). Está em estado precário, com o abdome quebrado, montado em um triângulo de cartolina junto com asa esquerda, pernas mediana esquerda e posteriores; a asa direita está quebrada no bordo costal; a probóscide 
está dissecada acondicionada em um tubinho com glicerina, ligado ao alfinete.

Um parátipo fêmea, etiquetado: "San Pablo. Chile/Oct. 1931 (etiqueta manuscrita)"; "Paratype No/49872/U.S.N.M. (etiqueta vermelha) (USNM). Está com o tegumento sujo e o abdome dissecado está acondicionado em um tubinho com glicerina.

Reconhecimento : coloração azul-violáceo metálica, com o abdome na metade apical do tergito $\mathrm{V}$ amarelo-alaranjado; pernas negras com tarsos em parte brancoamarelados. Macho: tibia I na face A e AV com pêlos cerdiformes longos em toda a face.

Coloração: coloração geral azul-violáceo metálica, com o abdome na metade do tergito $\mathrm{V}$ amarelo-alarnjado, mais evidente na fêmea. Antena castanho-escura com o segundo artículo pouco mais claro. Palpo castanho-escuro. Lúnula amarela com polinosidade prateada. Caliptras acastanhadas com bordos castanho-escuros. Pernas negras com os tarsos em parte branco-amarelados, mais evidentes nas pernas anteriores do macho; pulvilos amarelados.

Descrição. Macho: 7.25-8.08 mm. Asa: 7.25-7.83 mm.

Cabeça: olhos fortemente unidos, com numerosos cilios longos, afastados por um espaço que mede à altura do ocelo anterior $0.20-0.22 \mathrm{~mm}$; facetas anterointernas alargadas. Cerdas frontais longas e finas em número de $12-16$ pares iniciados ao nivel da inserção das antenas e terminados abaixo do nivel do ocelo anterior. Antena inserida abaixo da metade do olho, com o terceiro artículo medindo cerca de 1.6 vezes o segundo. Para faciália larga, ao nĩvel do ápice do segundo artículo antenal semelhante a largura da gena ao nivel inferior do olho. Palpo falciforme,

Tórax: de $2: 4$; acr $3: 2$; quatro cerdas umerais, duas mais fortes; uma pósumeral; uma prs; duas ia; pra forte, semelhante a npl anterior; duas sa, a posterior menor; duas psa, a posterior maior. Notopleura com duas cerdas, a posterior cerca de $2 / 3$ da anterior e sem cillios de revestimento. Escutelo com um par de cerda basal; dois laterais menores que o apical; um pré-apical fraco e um apical robusto. Uma cerda pro-episternal e uma pro-epimeral. Ctps 1:1, a posterior maior. Catepimero nu. Espiráculo posterior médio, ovalado. Caliptra inferior medindo cerca de 1.4 vezes a superior. Asa com veias R $4+5$ e M $1+2$ divergentes para o ápice. Coxa I sem esporão apical. Tỉbia na face A e AV com pélos cerdiformes longos em toda a face; face $\mathrm{V}$ com uma cerda na metade apical; face PD com 1:2 cerdas pequenas diferenciadas no terço apical. Tarso sem pêlos sensitivos longos; unhas e pulvilos desenvolvidos, semelhante ao comprimento do prétarso. Fêmur II na face PV com uma série de cerdas em toda a face. Tibia na face PV com quatro cerdas na metade do que o par anterior. Fêmur III na face AV com 5-6 cerdas filiformes no terço apical, algumas de ápice em gancho; face PV com pêlos cerdiformes longos no terço apical. Tíbia na face AV com duas séries de cerdas filiformes longas em toda a face e PV com uma; face AD com seis cerdas em toda a face; face PD com 5-6 cerdas em toda a face; calcar inserido no terço apical. Tarso como no par mediano.

Genitália: foi dissecado um parátipo proveniente de Llanquihue, Casa Pangue, Chile. Cercos, epândrio e surstilos (figs. 7 e 8); quinto esternito (fig. 9). Fêmea: $7,25 \mathrm{~mm}$. Asa: $7.08 \mathrm{~mm}$. 
Semelhante ao macho, diferindo no que segue: olhos curta e esparsamente ciliados, separados por um espaço de cerca de 0.37 da largura da cabeça; vita frontal com cerdas cruzadas inseridas ao nivel da metade; triângulo ocelar curto, cerca de um terço da vita frontal; cerdas frontais em número de nove pares, os dois superiores reclinados; antena inserida acima da metade do olho; tibia I na face AV com uma cerda no terço apical; face AD com uma série de cerdas curtas na metade basal; face PD nua; fêmur II na face PV com uma série de cerdas na metade basal.

Ovipositor: foi dissecado um parátipo proveniente de San Pablo, Chile. Ovipositor semelhante ao comprimento do abdome; microtríquias bem desenvolvidas nas membranas, ausente somente em algumas regiões do oitavo segmento; tergito VII estreito; esternito VIII esclerotinizado somente posteriormente (fig. 16).

Distribuição geográfica (fig. 74): CHILE (Osorno, Llanquihue) e ARGENTINA (Rio Negro).

\section{Palpibracus chilensis (Bigot)}

(Figs. 3, 10-12, 63, 75)

Yetodesia chilensis Bigot, 1885: 295 (desc. macho/fêmea).

Aricia chilensis; Stein, 1907:216 (rdesc. macho/fêmea).

Darwinomyia chilensis; Malloch, 1928: 314 (cit.; chave); Malloch, 1934 (rdesc. macho); Snyder, 1957: (rdesc. macho/fêmea).

Phaonia chilensis; Seguy, 1937: 331 (cat.).

Palpibracus chilensis; Pont, 1972: 17 (cat.).

Material-tipo: O material-tipo de Bigot não foi examinado e provavelmente encontra-se depositado no "British Museum Natural History" (cf SNYDER, 1957: 489).

Reconhecimento. Macho: fêmur II e III amarelos; fêmea com anel pré-apical negro, no fêmur III; tibia I na face AV com três cerdas da metade apical; face V com 3-4 cerdas no terço médio; fêmur II na face A com depressão na metade apical, sem pêlos de revestimento; tibia III na face AV com uma série dupla de cerdas no terço apical.

Coloração: coloração geral amarela com polinosidade cinzenta, com o tórax apresentando uma listra negra mediana, alargando-se para o escutelo e duas laterais, mais estreitas; escutelo amarelo-vivo; pleuras quase totalmente negras, exceto o catepimero; fêmeas: vita frontal avermelhada. Antena amarelo-alaranjada com o terceiro artículo castanho-escuro para o ápice. Palpo amarelado com base escurecida; nas fêmeas totalmente amarelo. Lúnula amarela com polinosidade prateada. Caliptras e balancim amarelos. Asa amarelada com as veias amarelo-alaranjadas. Pernas amarelas com o fêmur I castanho-escuro; pulvilos amarelados; fêmea; fêmur III com um anel pré-apical negro. Abdome negro com polinosidade cinzenta. 
Descrição.-Macho: $9.00-9.25 \mathrm{~mm}$. Asa: 8.40-8.50mm.

Cabeça: olhos fortemente unidos, com esparsos cilios curtos, afastados por um espaço que mede à altura do ocelo anterior $0.20-0.22 \mathrm{~mm}$; facetas anterointernas grandemente diferenciadas. Cerdas frontais em número de nove pares, iniciados ao nivel da lúnula e terminados abaixo do ocelo anterior. Antenas inseridas abaixo da metade dos olhos, com o terceiro artículo medindo cerca de 1.6 vezes o segundo. Parafaciália larga, ao nivel do ápice do segundo artículo antenal cerca de $2 / 3$ da largura da gena ao nivel inferior do olho. Palpo falciforme.

Tórax: de $2: 4$; acr $3: 2$; três cerdas umerais, duas maiores; uma pós-umeral; uma prs; duas ia; pra forte, semelhante a npl anterior; duas sa, a posterior menor; duas psa, a posterior maior. Notopleura com duas cerdas, a posterior cerca de $2 / 3$ da anterior e sem cilios de revestimento. Escutelo com um par de cerdas basal cerca de $3 / 5$ do lateral anterior; um lateral posterior menor que o apical; um pré-apical fraco e um apical robusto. Uma cerda pro-episternal e duas proepimerais. Ctps 1:3. Catepimero com 6-9 cilios. Espiráculo posterior desenvolvido, quadrangular. Caliptra inferior medindo cerca de 1.5 a superior. Asa com veias R $4+5$ e M $1+2$ divergentes para o ápice. Coxa I com forte esporão apical (dois espinhos unidos). Tibia na face AV com três cerdas na metade apical; face $\mathrm{V}$ com 3-4 cerdas no terço médio; face PD com 2-3 pequenas cerdas no quinto apical. Tarso sem pêlos sensitivos longos; unhas e pulvilos desenvolvidos, semelhante ao comprimento do pré-tarso. Fêmur II na face A com uma depressão mediana, sem pêlos de revestimento e com tufo de cillios fortes no bordo anterior; face $\mathrm{AV}$ com $3-4$ cerdas no terço basal; face A com série dupla de 5-6 espinhos curtos no terço apical. Tibia na face PD com 4-5 cerdas em toda a face; face P com duas e PV com 3-4 na metade apical. Unhas e pulvilos pequenos, menores que o par anterior. Fêmur III ligeiramente curvo; face AV com 34 cerdas fortes no terço apical. Tibia curva; face AV com série dupla de cerdas em toda a face; face $\mathrm{AD}$ com uma série de cerdas até o terço apical, as medianas, mais

fortes; face P com uma série de cillios no quarto apical; face PD com quatro cerdas em toda a face, o calcar o mais forte, inserido no terço apical; tarso como no par mediano.

Genitália: (foi dissecado o exemplar proveniente do Chile). Cercos, epândrio e surstilos (figs. 10 e 11); quinto esternito (fig. 12).

Fêmea: 7.50-7.92 mm. Asa: 7.25-7.50 mm

Semelhante ao macho, diferindo no que segue: olhos quase nus, separados por um espaço de cerca de 0.38 da largura da cabeça; vita frontal com um par de cerdas cruzadas e inseridas ao nível da metade; triângulo ocelar longo, cerca da metade da vita frontal; cerdas frontais em número de nove pares, com os dois superiores reclinados; antenas inseridas acima da metade do olho; tibia I na face AV com uma cerda submediana; face PD com quatro cerdas em toda a face; tibia III na face AD com três cerdas e na AV com série de 4-5 na metade apical; face PD com duas cerdas no terço médio, o calcar inserido no limite do terço apical.

Ovipositor: (foi dissecado um exemplar de Araucania (Chile). Ovipositor semelhante ao comprimento do abdome; microtríquias ausentes; tergito VII estreito (fig. 3). 
Material examinado: CHILE. 1 macho, E. C. Reed (USNM); Araucania (Chile), 1 macho, 1 fêmea, II.1888 (USNM). Curico: Rio Teno, 1 macho, 14.II.1965, L. E. Peña (MZSP). Malleco: Angol, 2 fêmeas, 16-21 XI.1970, T. Cekalovic (MZSP); ibidem, 4 fêmeas, 1-6.X.1970, T. Cekalovic (MZSP).

Distribuição geográfica (fig. 75): CHHLE (Curico, Malleco).

\section{Palpibracus confusus (Malloch)}

(Figs. 13, 16-18, 6, 76)

Darwinomyia univittata Malloch, 1922 (nec Bigot): 278 (desc. macho/fêmea). Darwinomyia confusa Malloch, 1928: 314 (cit., nom. nov. pro D. univittata Malloch, 1922); Malloch, 1934: 319 (desc. macho/fêmea); Snyder, 1957: 489 (desc. macho/fêmea).

Phaonia confusa; Seguy, 1937: 331 (cat.).

Palpibracus confusus; Pont, 1972: 17 (cat.).

Material-tipo: o holótipo macho não foi examinado e provavelmente encontra-se depositado no "British Museum Natural History" (Malloch, 1934).

Reconhecimento. Macho: fêmur III no 2/3 apical e tibia IIl negros; tỉbia I na face AV com duas cerdas na metade apical; face V de zero a duas pequenas cerdas no quinto apical; fêmur II na face A com uma depressão na metade apical; tibia III extremamente curva; face AV e A com série de cerdas em toda a face.

Coloração: coloração geral amarela com polinosidade cinzenta, com o tórax apresentando uma listra negra, larga, mediana que não atinge o escutelo e duas estreitas laterais, mais visǐveis pré-suturalmente; escutelo amarelo-vivo; anepisterno e anepimero, na metade inferior e pós-noto enegrecidos; fêmea geralmente com apenas a listra mediana, mais estreita do que a do macho com a vita frontal quase que totalmente avermelhada. Antena castanho-escura, com o primeiro, segundo e base do terceiro artículo amarelado. Palpo amarelado. Lúnula castanho-escura com polinosidade cinzenta. Caliptras e balancim amarelados. Asa amarelada com as veias amarelo-alaranjadas. Pernas amarelas, com o fêmur I, exceto o ápice, fêmur III nos $2 / 3$ apicais e tibia negros. Tibias e tarsos poucos escurecidos; pulvilos amarelados. Fêmea com as pernas menos extensivamente negras. Abdome negro com polinosidade cinzenta.

Descrição.-Macho: 7.17-7.92 mm. Asa: 7.75-8.08 mm.

Cabeça: olhos fortemente unidos, com numerosos cilios longos, afastados por um espaço que mede à altura do ocelo anterior $0.18-0.20 \mathrm{~mm}$; facetas anterointernas pouco diferenciadas. Cerdas frontais em número de nove pares iniciados ao nivel do segundo artículo antenal e terminados ao nivel do ocelo anterior. Antena inserida abaixo da metade do olho, com o terceiro artículo medindo cerca de 1.6 vezes o segundo. Parafaciália larga, ao nivel do ápice do segundo artículo antenal cerca de $2 / 3$ da gena ao nivel inferior do olho. Palpo falciforme.

Tórax: de 2-3: 4; acr 3:3; três cerdas umerais, duas mais fortes; $1-2$ pósumerais; uma prs; duas ia; pra forte, semelhante a npl anterior; duas sa, a posterior menor; duas psa, a posterior menor. Notopleura com duas cerdas, a anterior 
cerca de duas vezes a posterior e sem cilios de revestimento. Escutelo com um par de cerdas basal fraco; dois laterais menores que o apical; um pré-apical fraco e um apical robusto. Uma cerda pro-episternal. Ctps $1: 3$, a posterior maior. Catepimero com 4-7 cilios. Espiráculo posterior desenvolvido, quadrangular. Caliptra inferior medindo cerca de 1.4 vezes a superior. Asa com as veias R $4+5$ e M $1+2$ divergentes para o ápice. Coxa I com forte esporão apical (dois espinhos longos unidos). Tibia na face AV com duas cerdas na metade apical; face V com 3.4 cerdas filiformes no terço apical; face PD com zero a duas pequenas cerdas no quinto apical. Unhas e pulvilos desenvolvidos, semelhante ao comprimento do pré-tarso. Fêmur II na face anterior com uma depressão na metade apical e um grupo de cerdas na metade basal do bordo anterior; face AV com 6-7 cerdas eretas e fortes no terço basal e face A com 4-6 espinhos curtos no terço apical. Tibia na face PD com 4-5 cerdas em toda a face; face P com duas e PV com 3-5 na metade apical. Unhas e pulvilos pequenos, menores que o comprimento do pré-tarso. Fêmur III ligeiramente curvo; face AV com 3-4 cerdas fortes no terço apical. Tibia extremamente curva; face A e AV com uma série de cerdas longas e finas em toda a face; face AD com uma série de cerdas fortes em toda a face; face P com uma série dupla de cerdas longas no terço apical semelhante a face AV; face PD com 3-5 cerdas em toda face, o calcar mais forte e inserido no terço apical.

Genitália: (foi dissecado um exemplar proveniente de El Coigual, Curicó, Chile). Cercos, e pândrio e surstilos (figs. 16 e 17); quinto esternito (fig. 18).

Fêmea: 7.92-8.50. Asa: 7.75-8.20 mm.

Semelhante ao macho diferindo no que segue: olhos quase nus, separados por um espaço de cerca de 0.39 da largura da cabeça; vita frontal com um par de cerdas interfrontais cruzadas e inseridas ao nivel da metade; triângulo ocelar curto, cerca de um terço da vita frontal; cerdas frontais em número de 8-9 pares, com os superiores reclinados; antenas inseridas acima da metade do olho; tibia I na face AV com uma cerda submediana; face PD com 3-4 cerdas em toda a face; tibia II na face PV com 1-3 cerdas na metade apical; tibia III na face AD com três cerdas em toda a face e AV com 4-6 na metade apical; face PD com $2-3$ cerdas no $2 / 3$ basais, calcar o mais forte e insrido no limite do terço apical.

Ovipositor: (foi dissecado um exemplar proveniente de Cerros de Nahuelbuta, Angol, Chile). Ovipositor cerca de 1.5 vezes o comprimento do abdome; microtríquias ausentes; tergito VII estreito (fig. 13).

Material examinado: CHILE. Curicó: El Coigual (Cord Curicó), 4 machos, I.1964. L. E. Peña (MZSP); ibidem, La Invernada, 1 fêmea, 07.I.1968, L. E. Peña (MZSP). Nuble: Las Trancas (Cord. Chillian), 1 fêmea, 24.III.1968 (MZSP); ibidem, 1 macho, I.1970 (MZSP). Concepcion, 1 fêmea, 9-13.XI.1970, T. Cekalovic (MZSP). Malleco: Angol, 1 fêmea, 28.III.1925 (USNM); ibidem (Cerros de Nahuelbuta), 500m, 1 fêmea, II.1934, D. S. Bullock (USNM); ibidem, 1 fêmea, 1.XI.1936, D. S: Bullock (USNM); ibidem, 1 fêmea, 16-21.XI.1970, T. Cekalovic (MZSP). Cautin: Lonquimay, 1 macho, L. E. Peña (MZS). Llanquihue: Salto, 1 fêmea, I.1932, E. R. Reed (BMNH). Chiloé: Dalcahue, I. Chiloé, 3 fêmeas, .1962, L. E. Peña (MZSP). ARGENTINA. Chubut: Lago Kruger, 1 macho, 17.II.1949, Abaviros (IML). 
Distribuição geográfica (fig. 76): CHILE (Curicó, Nuble, Concepcion, Bio Bio, Malleco, Chiloé); ARGENTINA (Chubut, Santa Cruz).

\author{
Palpibracus fasciculatus (Malloch) \\ (Figs. 14, 19-21, 64, 77)
}

Darwinomyia fasciculata Malloch, 1934: 332 (desc. macho); Snyder, 1957: 489 (desc. fêmea).

Palpibracus fasciculatus; Pont, 1972: 17 (cat.).

Material-tipo: holótipo macho, etiquetado: "Correritoso/Rio Negro/ ArgNov1926 (Argentina, XI.1926)/R \& EShannon"; HOLOTYPE No/49769/ U.S.N.M. (etiqueta vermelha)"; "Darwinomyia/fasciculata/type/det. JR Malloch (etiqueta manuscrita do Maloch)" (USNM). Está em bom estado; quase todas as cerdas intactas; o abdome dissecado está acondicionado em tubinho com glicerina.

Reconhecimento. Macho: tibia III na face PV com uma série de cilios finos que no terço mediano se alongam formando um conspicuo pincel.

Coloração: coloração geral amarelo-metálica com polinosidade cinzenta, com o tórax apresentando listra negra larga, mediana que atinge o escutelo; catepimero, meron e pós-noto enegrecidos. Fêmea com a listra dorsal estreita, limitada às acr; vita frontal avermelhada em quase toda a extensão. Caliptras e balancim amarelados. Asa amarelada com as veias castanhas. Pernas castanhoclaras; pulvilos amarelados; nas fêmeas as pernas são escurecidas. Abdome negro com discreta polinosidade cinzenta.

Descrição.-Macho: 7,50mm. Asa: $7.25 \mathrm{~mm}$.

Cabeça: olhos fortemente unidos, com numerosos cilios longos afastados por um espaço que mede a altura do ocelo anterior $0.16 \mathrm{~mm}$; facetas anterointernas pouco diferenciadas. Cerdas frontais em número de 10 pares, iniciados ao nǐvel da lúnula e terminados abaixo do nǐvel do ocelo anterior, os superiores filiformes. Antena curta, inserida abaixo da metade do olho, com o terceiro artǐculo medindo cerca de 1.5 vezes o segundo. Parafaciália larga, ao nǐvel do ápice do segundo artículo antenal cerca de 2/3 da largura da gena ao nível inferior do olho. Palpo falciforme.

Tórax: de $2: 4$; acr $2: 2$; três cerdas umerais, duas mais fortes; uma pós-umeral; uma prs; duas ia; pra forte, semelhante a npl anterior; duas sa, a posterior menor, duas psa, a posterior maior. Notopleura com duas cerdas, a posterior cerca da metade da anterior e sem cílios de revestimento. Escutelo com um par de cerdas basais, dois laterais menores que o apical; um pré-apical fraco e um apical robusto. Uma cerda pro-episternal e uma pro-epimeral. Ctps 1:3. Catepimero nu. Espiráculo posterior quadrangular, desenvolvido. Caliptra inferior medindo cerca de 1,5 vezes a superior. Asa com as veias R $4+5$ e $\mathbf{M} 1+2$ divergentes para o ápice. Coxa I sem esporão apical. Tỉbia na face AV com 2-3 cerdas submedians, somente a superior forte e face V com quatro cerdas filiformes no terço apical. Tarso sem pêlos sensitivos longos; unhas e pulvilos pequenos, me- 
nores que o comprimento do pré-tarso. Fêmur II na face AV e PV com 2.3 cerdas fortes na base. Tỉbia na face PV com 2-3 cerdas no terço médio; face PD com 6-7 cerdas. Tarso como no par anterior. Fêmur III levemente curvo; face AV com 3-4 cerdas fortes no terço apical. Tibia curva; face AD com cinco cerdas em toda a face; face PV com uma série de cílios finos que no terço mediano se alongam formando um conspicuo pincel; face PD com o calcar inserido no quarto apical. Tarso como no par anterior.

Genitália( (foi dissecado o holótipo) cercos, epândrio e surstilos (figs. 19 e 20); quinto esternito (fig. 21).

Fêmea: 7.00-7.50 mm. Asa: 6.67-7.17 mm.

Semelhante ao macho, diferindo no que segue: olhos curta e esparsamente ciliados, separados por um espaço de cerca de 0.36 da largura da cabeça; vita frontal com cerdas cruzadas e inseridas ao nĩvel da metade; triângulo ocelar curto, cerca de um terço da vita frontal; cerdas frontais em número de oito pares, os dois superiores reclinados; antena inserida acima da metade do olho; tibia II na face V com uma cerda submediana; tibia III na face AV com 2-3 cerdas no terço médio; fêmur III curvo e levemente intumescido pré-apicalmente.

Ovipositor: (foi dissecado um exemplar proveniente de Lago Argentino, Santa Cruz, Argentina). Ovipositor cerca de 1.5 vezes o comprimento do abdome; microtríquias ausentes; tergito VII estreito (fig. 14).

Material examinado: CHILE. Chiloé: Dalcahue, 1 fêmea, I. 1962, L. E. Peña (MZSP). ARGENTINA. Santa Cruz: Brazo Oriello (lago Argentino), 1 fêmea, 25.II.1963, Willink (IML).

Distribuição geográfica (fig. 77): CHILE (Chiloé); ARGENTINA (Rio Negro, Santa Cruz).

\section{Palpibracus lancifer (Malloch) \\ (Figs. 15, 22-24, 65, 78)}

Darwinomyia lancifer Malloch, 1934: 326 (desc. macho/fêmea).

Palpibracus lancifer; Pont, 1972: 17 (cat.).

Material-tipo: holótipo macho, etiquetado: "Correntoso/Rio Negro/Agr Nov1926 (Argentina, XI.1926)R \& EShannon"; "HOLOTYPE No/49772/U.S. N. M. (etiqueta vermelha)"; "Darwinomyia/lancifer/type/det. JRMalloch (etiqueta manuscrita de Maloch) (USNM). Está em bom estado, com a quetotaxia quase completa; asa esquerda quebrada no bordo costal. Abdome dissecado em um tubinho com glicerina.

Alótipo fêmea, etiquetado: "Bariloche/Rio Negro/AgrNov1926 (Argentina, XI.1926)/R \& Shannon"; "Allotype No/49772/U.S.N.M. (etiqueta vermelha); Darwinomyia/lancifer/allotype No/49772/U.S.N.M. (etiqueta manuscrita de Malloch) (USNM). Está em excelente estado; quetotaxia completa.

Reconhecimento: azul-violáceo metálico, com as pernas amarelas. Macho: coxa I com forte esporão apical; tibia I na face V com 6-7 cerdas filiformes no terço médio; tibia İII curva, na face AV e V com cerdas longas de ápice curvo; face $\mathrm{P}$ com uma série de cerdas longas a partir do quarto apical. 
Coloração: coloração geral azul-violáceo metálica com polinosidade branca, apresentando no tórax duas listras pré-suturais pouco evidentes. Antena e palpo castanho-escuros. Fêmea com a vita frontal castanho-escura, pouco avermelhada anteriormente. Caliptras e balancim amarelados; nos machos este com a haste castanho. Asa amarelada, com a base amarela e veias castanhas. Pernas amarelas com as coxas, trocanteres e tarsos negros; fêmeas com os ápices dos fêmures castanho-escuros; pulvilos amarelados.

Descrição.-Macho: $6.83 \mathrm{~mm}$. Asa: $7.17 \mathrm{~mm}$.

Cabeça: olhos fortemente unidos, com esparsos cillios curtos, afastados por um espaço que mede a altura do ocelo anterior $0,16 \mathrm{~mm}$; facetas anterointernas não diferenciadas. Cerdas frontais em número de oito pares, iniciados ao nǐvel da lúnula e terminados abaixo do nĩvel do ocelo anterior. Antena longa, inserida abaixo da metade do olho, com o terceiro artículo medindo 2.1 vezes o segundo. Parafaciália larga, ao nǐvel do segundo artǐculo antenal medindo cerca de $2 / 3$ da largura da gena ao nĭvel inferior do olho. Palpo falciforme.

Tórax: de $2: 4$; acr $3: 1$; três umerais, duas mais fortes; uma pós-umeral; uma prs; uma ia; pra forte, semelhante a $\mathrm{npl}$ anterior; duas sa, a posterior filiforme; duas psa, a posterior maior. Notopleura com duas cerdas, a posterior cerca de $2 / 3$ da anterior e sem cílios de revestimento. Escutelo com um par de cerdas basais; dois laterais menores que o apical; um apical robusto. Uma cerda pro-episternal e uma pro-epimeral. Ctps 1:3, a posterior maior. Catepimero nu. Espiráculo posterior quadrangular, desenvolvido. Caliptra inferior medindo cerca de 1.7 vezes a superior. Asa com as veias $\mathrm{R} 4+5$ e $\mathrm{M} 1+2$ divergentes para o ápice. Coxa I com esporão apical. Tibia na face AV com duas cerdas na metade apical; face $V$ com série de 6-7 cerdas ciliformes eretas no terço médio; face PD com uma cerda no quinto apical. Tarso sem cillios sensitivos longos; unhas e pulvilos pequenos, menores que o pré-tarso. Fêmur II curvo; face $\mathrm{AD}$ com uma série de seis cerdas curtas no quarto apical. Tíbia na face $\mathrm{P}$ com cinco cerdas longas e fortes em toda a face; face PV com três cerdas no terço médio. Tarso como no par anterior. Fêmur III curvo; face AV, A, AD com cerdas fortes no terço apical. Tíbia curva; face AD com 5-6 cerdas, em toda a face, menores para a base; face $\mathrm{AV}$ e V com cerdas longas de ápice curvo; face $\mathrm{P}$ com uma série de cerdas longas a partir do quarto basal, maiores para o ápice; face PD com o calcar inserido no quarto apical. Tarso como no par anterior.

Genitália: (foi dissecado o holótipo) cercos, epândrio e surstilos (figs. 22 e 23 ); quinto esternito (fig. 24).

Fêmea: 8.50-8.67 mm. Asa: 7.92-8.33 mm.

Semelhante ao macho, diferindo no que segue: olhos separados por um espaço de cerca de 0.35 da largura da cabeça; vita frontal com cerdas intercruzadas inseridas ao nǐvel da metade; triângulo ocelar longo, cerca da metade da vita frontal; cerdas frontais em número de 7.8 pares, os dois superiores reclinados; antena inserida acima da metade do olho; coxa I com duas cerdas fortes juntas, na posição do esporão apical do macho; tibia I na face AV com uma cerda no terço médio; face PD com duas pequenas cerdas no limite do terço apical; fêmur II na face PV com uma cerda forte isolada no terço basal.

Ovipositor: (foi dissecado um exemplar proveniente de Pucatrihue, Osor- 
no, Chile). Ovipositor cerca de 1.5 vezes o comprimento do abdome; microtriquias ausentes; esternito VI e VII fortemente modificados, não divididos posteriormente (fig. 29).

Material examinado: CHILE. Osorno: Pucatrihue, 1 fêmea, II.1967, L. E. Peña (MZSP).

Distribuição geográfica (fig. 78): CHILE (Osorno); ARGENTINA (Rio Negro).

\section{Palpibracus nigriventris (Malloch)}

(Figs. 25, 28-30, 66, 79)

Darwinomyia nigriventris Malloch, 1928: 314 (desc. fêmea); Malloch, 1934: 331 (desc. macho/fêmea).

Phaonia nigriventris; Seguy, 1937: 335 (cat.).

Palpibracus nigriventris; Pont, 1972: 17 (cat.).

Material-tipo: Holótipo fêmea não foi examinado e está depositado no USNM (R. A. Gagné, in litt. 29.I.1983) e segundo D. O. Albuquerque (comunicação pessoal) encontra-se em bom estado.

Parátipo fêmea, etiquetado: "Chile/Faz (A. Faz), 1924 (etiqueta manuscrita)"; "232 (etiqueta manuscrita)"; "Paratype No./49973/U.S.N.M. (etiqueta vermelha)". O parátipo fêmea está em condição precária, com o tegumento sujo, faltando as pernas anteriores e medianas, tarso posterior direito e cerca da metade da asa direita; a maioria das cerdas torácicas estão quebradas.

Reconhecimento: tórax amarelo com uma lista negra, larga, mediana. Macho: tỉbia III na face PV com uma série dupla de cỉlios, terminados em um grupo de 6-7 cillios longos de ápice curvo. Fêmea: vita frontal castanho-escura com a metade anterior levemente avermelhada.

Coloração: coloração geral amarela com o tórax apresentando uma listra negra mediana, que atinge as dc; escutelo amarelo-claro, catepisterno, meron e catepimero negros. Fêmea com vita frontal castanho-escura com a metade anterior levemente avermelhada. Antena castanho-escura com o ápice do segundo artículo mais claro. Palpo castanho-escuro. Lúnula amarela com polinosidade prateada. Caliptras amareladas e balancim castanho com haste amarela. Asa amarelada com as veias castanho-claras; pulvilos amarelados. Abdome negro com discreta polinosidade cinzenta.

Descrição.-Macho: 5.92-7.00 mm. Asa: 6.33-7.42 mm.

Cabeça: olhos fortemente unidos, com numerosos cílios curtos, afastados por um espaço que mede à altura do ocelo anterior 0.12-0.14 mm; facetas anterointernas grandemente alargadas. Cerdas frontais em número de 8-10 pares, iniciados ao nivel da lúnula e terminados abaixo do nĩvel do ocelo anterior, os superiores filiformes. Antena inserida abaixo da metade do olho, com o terceiro articulo medindo cerca de 1.5 vezes o segundo. Parafaciália estreita, ao nivel do segundo artículo antenal cerca da metade da gena ao nível inferior do olho. Palpo falciforme. 
Tórax: de 2:4; acr 2:2-3; duas cerdas umerais; uma pós-umeral; uma prs; duas ia; pra forte, semelhante a $\mathrm{npl}$ anterior e sem cillios de revestimento; duas sa, a posterior menor; duas psa, a posterior maior. Escutelo com um par de cerda basal fraco; dois laterais menores que o apical; um pré-apical filiforme e um apical robusto. Uma cerda pro-episternal e uma pro-epimeral. Ctps 1:2-3, a posterior maior. Catepimero nu. Espiráculo posterior médio, ovalóide. Caliptra inferior medindo cerca de 1.6 vezes a superior. Asa com as veias $R 4+5$ e M $1+2$ paralelas para o ápice. Coxa I sem esporão apical. Tibia na face AV com uma cerda submediana e na face PD com 1-2 pequenas no terço apical. Tarso sem pêlos sensitivos longos; unhas e pulvilos pequenos, menores que o comprimento do pré-tarso. Fêmur II na face PV com 2-3 cerdas fortes. Tibia na face PV com 1.2 cerdas, a mediana mediocre; face PD com quatro cerdas. Tarso como no par anterior. Fêmur III na face AV com 2-3 cerdas fortes no terço apical. Tíbia discretamente curva; face AD com três cerdas; face AV com uma série de cerdas, duplicadas na metade basal; face PV com série dupla de cillios, terminada em um grupo de 6-7 cílios longos de ápice curvo, no terço mediano, face PD com o calcar inserido no quarto apical. Tarso como no par anterior.

Genitália: (foi dissecado um exemplar proveniente de Dalcahue, Chiloé, Chile e um de El Coigual, Cordilheira de Curicó, Chile). Cercos, espândrio e surstilos (figs. 28 e 29); quinto esternito (fig. 30).

Fêmea: $7.08-8.25 \mathrm{~mm}$. Asa: $6.83-7.67 \mathrm{~mm}$.

Semelhante ao macho, diferindo no que segue: olhos curta e esparsamente ciliados, separados por um espaço de cerca de um terço da largura da cabeça; vita frontal com cerdas cruzadas e inseridas ao nivel da metade; triângulo ocelar longo, cerca da metade da vita frontal; cerdas frontais em número de sete pares, os dois superiores reclinados; antena inserida acima da metade do olho; tibia III na face AV com $2-4$ cerdas medianas.

Ovipositor: (foi dissecado um exemplar proveniente de Dalcahue, Chiloé, Chile). Ovipositor cerca de 1,5 vezes maior que o comprimento do abdome; microtrĭquias pouco desenvolvidas, somente nas regiões laterais do oitavo segmento: tergito VII estreito (fig. 25).

Material examinado: CHILE. Curicó: El Coigual (Cord. Curicó), 1 fêmea, I.1964, L. E. Peña (MZSP). Malleco: Angol, 1 fêmea, 27.III.1930 (USNM). Cautin: Lago Galletue (Cord. Lonquimay), 1 fêmea, I.1962, L. E. Peña (MZSP); Termas do Rio Blanco, 1 fêmea, 28.III.1938 (USNM). Llanquihue: Hornohuinco (N. de Correntoso), 2 machos, 3 fêmeas, III.1968, L. E. Peña (MZSP); ibidem, 1 macho, XII.1968, L. E. Peña (MZSP). Chiloé: Dalcahue, I. Chiloé, 26 machos, 33 fêmeas, I.1962, L. E. Peña (MZSP); ibidem, 6 machos, 8 fêmeas, IV.1968, L. E. Peña (MZSP). Magallanes: Rio las Minas, 1 macho, 10-15.I.1966, Flint \& Cekalovic (USNM); 1 macho, B. M. 1927-63, F. \& M. Edwards (BMNH). ARGENTINA. Neuquen: Pucará (Parq. Nac. Lanin), XI.1952-II.1953, Schazovskoi (IML). Rio Negro: Bariloche, 2 machos, XI. 1926, R. \& E. Shannon (USNM). Santa Cruz: Lago Argentino, 1 fêmea, 26.II.1950, Willink (IML).

Distribuição geográfica (fig. 79): CHILE (Curicó, Malleco, Cautin, Llanquihue, Chiloé, Magallanes); ARGENTINA (Neuquen, Rio Negro, Santa Cruz). 
Palpibracus peruvianus (Malloch), comb. n.

$$
\text { (Figs. 26, 31-33, 80) }
$$

Phaonia peruviana Malloch, 1929: 325 (desc. macho); Seguy, 1937a: 336 (cat.); Albuquerque, 1958: 35 (pcat.); Pont, 1972: 15 (cat.).

Darwinomyia angolensis Malloch, 1934: 334 (desc. macho/fêmea), Syn.n. Palpibracus angolensis; Pont, 1972: 17 (cat.).

Material-tipo: holótipo macho de Phaonia peruviana Malloch, etiquetado: Perales (Chile)/I-25 (etiqueta manuscrita)"; type No./42226/U.S.N.M. (etiqueta vermelha)"; "Phaonia/peruviana/Det. J. R. Malloch type (etiqueta manuscrita de Malloch)". Está em estado ruim; falta perna posterior direita; cabeça colada na etiqueta de procedência; perna posterior esquerda e mediana coladas em uma etiqueta triangular; abdome dissecado em um tubinho com glicerina.

O holótipo de D. angolensis não foi examinado; segundo D. O. Albuquerque (comunicação pessoal) está depositado no USMN e encontra-se em bom estado.

O alótipo de D. angolensis é um exemplar não totalmente esclerotinizado, com todas as cerdas destruídas, faltando as pernas anteriores; abdome dissecado em tubinho com glicerina.

Alótipo de D. angolensis Malloch, etiquetado: "Bariloche/Rio Negro/ AgrNov1926 (Argentina,XI.1926)/R \& EShannon”; "Allotype No./49771/ U.S.N.M. (etiqueta vermelha)"; "Palpibracus/angolensis (etiqueta manuscrita branca)".

Reconhecimento: coloração negra com o tórax apresentando três listras polinosas cinzentas; úmero, região supra-alar, calo pós-alar e escutelo amarelo. Abdome negro com polinosidade cinzenta, apresentando o tergito I-II e III amarelo translúcido, com listra estreita castanha central; IV com manchas amarelas difusas e $\mathrm{V}$ com ápice amarelo; placa central com uma incisão que ocupa quase toda extensão medianamente. Abdome da fêmea amarelo-opaco.

Coloração: negra com o tórax apresentando três listras polinosas cinzentas; úmero, região supra-alar, calo pós-alar e escutelo amarelo. Vita frontal da fêmea amarela. Antena castanho-escura com ápice do segundo artículo mais claro. Palpo amarelado com a base castanho. Lúnula amarela com polinosidade prateada. Caliptras branco-amareladas e balancim amarelado. Asa amarelada com as veias castanho-claras. Pernas castanho-escuras com os ápices dos fêmures e tỉbias mais claras; fêmur II na face A pré-apicalmente amarelado; pulvilos branco-amarelados. Abdome negro com polinosidade cinzenta apresentando o tergito I-II e III amarelo-translúcido com listra estreita central, castanha; IV com manchas amarelas difusas e V com ápice amarelo. Fêmeas com o abdome inteiramente amarelo-opaco.

Descrição.-Macho: 6.50-7,30 mm. Asa: 7.00-7.50 mm.

Cabeça: olhos fortemente unidos, com númerosos cilios curtos, afastados por um espaço que mede à altura do ocelo anterior $0.16-0.20 \mathrm{~mm}$; facetas anterointernas alargadas. Cerdas frontais em número de 6-8 pares iniciados ao nǐvel da lúnula e terminados abaixo do nivel do ocelo anterior, os superiores filiformes. Antena inserida acima da metade do olho, com o terceiro artǐculo 
medindo cerda de 1.8 vezes o segundo. Parafaciália ao nível do segundo artículo antenal cerca de $2 / 3$ da largura da gena, ao nivvel inferior do olho. Palpo falciforme.

Tórax: dc 2:4; acr 2:1-2; três cerdas umerais, duas mais fortes; uma pósumeral; uma prs; duas ia; pra forte, semelhante a npl anterior; duas sa; duas psa. Notopleura com duas cerdas, a posterior cerca da metade da anterior e sem cillios de revestimento. Escutelo com um par de cerdas basais; dois laterais menores que o apical; um pré-apical fraco e um apical robusto. Uma cerda pro-episternal e duas pro-epimerais. Ctps 1:3, a posterior maior. Catepimero nu. Espiráculo posterior oval, desenvolvido. Caliptra inferior medindo cerca de 1.3 vezes a superior. Asa com as veias R $4+5$ e M $1+2$ divergentes para o ápice. Coxa I sem esporão apical. Tỉia na face AV com uma cerda submediana; face PD com duas cerdas diferenciadas no terço apical. Tarso sem pêlos desenvolvidos longos; unhas e pulvilos desenvolvidos, maiores que o comprimento do pré-tarso. Fêmur II na face PV com 5-7 cerdas na metade basal. Tibia na face PV com duas cerdas na metade apical; face PD com 3-5 cerdas em toda a face. Tarso como no par anterior. Fêmur III na face AV com série de cerdas, maiores na metade apical, algumas com ápice curvo. Tibia na face $\mathrm{AD}$ com 3-4 cerdas e face $\mathrm{AV}$ com 4-5 em toda a face, dupla na metade basal; face PV com uma série de cilios diferenciados em toda a face, notadamente na base; face PD com o calcar inserido no quarto apical. Tarso como no par anterior.

Genitália: (foi dissecado o holótipo e um exemplar proveniente de Curicó, Chile). Cercos, epândrio e surstilos (figs. 31 e 32); quinto esternito (fig. 33).

Fêmea: $7.00 \mathrm{~mm}$. Asa: $6.75 \mathrm{~mm}$.

Semelhante ao macho, diferindo no que segue: olhos quase nus, separados por um espaço de cerca de 0.33 da largura da cabeça; vita frontal com cerdas intercruzadas e inseridas ao nível da metade; triângulo ocelar grande, cerca da metade da vita frontal. Tíbia II na face AV com uma cerda mediana. Tibia III na face $\mathrm{AV}$ e $\mathrm{AD}$ com duas cerdas na metade apical.

Ovipositor: (foi dissecado o alótipo de D. angolensis) ovipositor cerca de 1,5 vezes maior que o comprimento do abdome; microtrĭquias ausente; tergito VII estreito (fig. 26).

Notas sobre a localidade-tipo: MALLOCH (1929 :326) cita Perales, Peru, como localidade do tipo de Phaonia peruviana e Perrone como coletor. Após examinar o material-tipo, não encontrado estas informações e comparando com diversas etiquetas do mesmo modelo de Flaminio Ruiz P., não temos dúvida em afirmar que este foi o coletor e que Perales de Malloch (loc. cit.) fica no Chile. Perales é um nome espanhol bastante comum. RUIZ (1926:158) relatou uma excursão em diversas localidades do Chile entre os meses de XII.1924 e II.1925.

Material examinado: CHILE. Curicó: Rio Teno, 1 macho, 14.II.1965, L. E. Peña (MZSP).

Distribuição geográfica (fig. 80): CHILE (Curicó, Bio Bio); ARGENTINA (Rio Negro). 
Vol. 6(2), 1989

\section{Palpibracus pilosus (Macquart)}

(Fig. 81)

Brachypalpus pilosus Macquart, 1851: 260 (desc. macho); Seguy, 1937:318 (cat.).

Palpibracus pilosus; Rondani, 1864: 35 (cit.); Albuquerque, 1951: 7 (rdesc. macho); Pont, 1972:17 (cat.).

Material-tipo: o holótipo macho não foi examinado e encontra-se depositado no "Museum National d'Histoire Naturelle" em Paris. "O material está em mau estado, faltando pernas médias e a coloração em parte sacrificada . . ." (ALBUQUERQUE, 1951:7).

Considerações: Exemplares desta espécie não foram encontradas entre o material que deu origem a este trabalho. Por isso, foi feita uma redescrição do holótipo baseado no trabalho de ALBUQUERQUE (1951:7). Na chave de identificação, $P$. pilosus está colocada tentativamente na dicotomia sete, segregada de $P$. confusus pela quetotaxia das pernas.

Reconhecimento. Macho: amarela com listra torácica negra, mediana. Antena amarela; catepimero ciliado; coxa I com forte esporão; tibia I na face AV com uma série de cerdas fracas na metade basal; tibia III na face PV e V com cerdas filiformes e maiores para o ápice.

Coloração: amarela, com uma listra mediana, dorsal negra; anepisterno, anepimero, catepisterno - ângulo antero-superior, catepimero e parte do meron negros. Antena e palpo amarelos. Caliptras e balancim amarelos. Asa amarelada com as veias castanhas. Pernas amareladas com o fêmur I castanho-escuro no terço médio. Abdome negro com polinosidade cinzenta.

Descrição.-Macho: $7 \mathrm{~mm}$. Asa: ? $6 \mathrm{~mm}$ (provavelmente a escala de Albuquerque $(1951: 8)$ está incorreta.

Cabeça: olhos fortemente unidos, com numerosos cilios longos, afastados por um espaço que mede à altura do ocelo anterior $0,30 \mathrm{~mm}$. Antena curta, inserida abaixo da metade do olho, com o terceiro artículo medindo cerca de duas vezes o segundo.

Tórax: de 2:4; acr 3:?; três cerdas umerais; uma pós-umeral; uma prs; duas ia; pra forte, semelhante a npl anterior; duas sa. Escutelo com dois pares de cerdas laterais; um pré-apical e um apical. Ctps 1:3. Catepimero ciliado. Asa com as veias $\mathrm{R} 4+5$ e M $1+2$ divergentes para o ápice. Coxa I com forte esporão apical. Tỉbia na face AV com uma série de cerdas fracas na metade basal; face PD com uma cerda mediana. Fêmur III curvo; face AV com uma série de cerdas na metade apical, as apicais mais fortes. Tỉbia curva; face $\mathrm{AD}$ com uma série de sete cerdas em toda a face; face AV com uma série de pequenas cerdas em toda a face; face PV e V com pêlos filiformes e maiores e mais densos para o ápice; face PD com três cerdas no terço médio, o calcar inserido no limite do terço médio.

Fêmea: desconhecida. 
Revta bras. Zool.

\section{Palpibracus reynoldsi (Malloch)}

(Figs. 27, 34-36, 67, 82)

Darwinomyia reynoldsi Malloch, 1934: 323 (desc. macho/fêmea).

Palpibracus reynoldsi; Pont: 17 (cat.).

Material-tipo: o holótipo macho não foi examinado e provavelmente encontra-se depositado no "British Museum Natural History" (MALLOCH, 1934).

Reconhecimento: calcar submediano. Macho: coloração geral negra com poucas regiões amarelas; tíbia III na face AV e A com uma série de cerdas em toda a face, esta mais forte; face AV com cerdas filiformes, duplicadas e maiores na metade apical. Fêmea: tibia III na face AV com uma série de cerdas filiformes na metade apical.

Coloração: negra com três listras polinosas cinzentas no tórax; úmero e região supra-alar, pós-supra alar e escutelo amarelo-alaranjado. Fêmeas com a coloração do tórax amarelo-alaranjada e uma listra negra larga, mediana; vita frontal totalmente avermelhada. Anepisterno, anepimero, região posterior do meron e parte do pós-noto negras. Antena castanho-escura com o primeiro e segundo artículo amarelo. Palpo amarelo-alaranjado. Lúnula amarela com polinosidade prateada. Caliptras amareladas e balancim amarelo com a haste castanho. Asa hialina com as veias castanhas. Pernas amarelas, com as coxas quase que totalmente negras; fêmur I, e fêmur III nos $2 / 3$ apicais negros, exceto os ápices; tibias e tarsos ligeiramente escurecidos, estes mais evidentes; pulvilos amarelados. Abdome negro com polinosidade cinzenta.

Descrição.-Macho: 7.63-8.33 mm. Asa : 8.00-8.50 mm.

Cabeça: olhos fortemente unidos, com numerosos cilios longos afastados por um espaço que mede à altura do ocelo anterior 0.20-0.22 $\mathrm{mm}$; facetas anterointernas pouco diferenciadas. Cerdas frontais fortes, em número de $9-11$ pares, iniciados ao nivel do segundo artículo antenal e terminados abaixo do nivel do ocelo anterior. Antena curta, inserida abaixo da metade do olho, com o terceiro artǐculo medindo cerca de 1,3 vezes o segundo. Parafaciália larga, ao nǐvel do segundo artǐculo antenal, da mesma largura da gena ao nivvel inferior do olho. Palpo filiforme.

Tórax: de $2: 4$; acr $3: 3$; três cerdas umerais, duas mais fortes; 1 -2 pós-umerais; uma prs; duas ia (às vezes quatro); pra forte, semelhante a npl anterior; duas sa, a posterior menor; duas psa, a posterior maior. Notopleura com duas cerdas, a anterior cerca de 1.5 vezes a posterior. Escutelo com um par de cerdas basais; dois laterais, o anterior mais forte; um pré-apical filiforme e um apical robusto. Uma cerda pro-episternal e duas pro-epimerais. Ctps 1:3, a posterior maior. Catepimero com 5-10 cillios. Espiráculo posterior, médio, ovalado. Caliptra inferior medindo cerca de 1.3 a superior. Asa com as veias $\mathrm{R} 4+5$ e M $1+2$ divergentes para o ápice. Coxa I com esporão apical. Tíbia na face AV com 2-3 cerdas longas e finas na metade apical; face V com 4-5 cilios longos; face PD nua. Tarso sem cilios sensitivos longos; unhas e pulvilos longos, maiores que o comprimento do pré-tarso. Fêmur II na face A sem depressão mediana e com os pêlos de revestimento normais; face A com um grupo de cerdas no terço basal 
e 3-4 espinhos curtos no terço apical; face PV com uma dupla série de cerdas fortes e curtas no terço basal. Tỉbia na face PD com 4-6 cerdas em toda a face; face P com duas cerdas medianas e PV com 2-4 no terço médio. Unhas e pulvilos curtos, menores que o comprimento do pré-tarso. Fêmur III discretamente curvo; face AV com 4-5 cerdas no terço apical. Tibia curva; face AV com cerdas filiformes em toda a face, duplicadas e maiores na metade apical; face A com série de cerdas fortes; face $A D$ com uma série de 5-6 cerdas em toda a face; face PD com uma série de cerdas em toda a face, o calcar mais forte e inserido submedianamente; face P e PV com séries de cilios longos em toda a face, maiores para o ápice. Tarso como no par mediano.

Genitália: (foi dissecado um exemplar proveniente de Punta Arenas, Chile). Cercos, epândrio e surstilos (figs. 34 e 35); quinto esternito (fig. 36).

Fêmea: $8.25-9.17 \mathrm{~mm}$. Asa: $7.67-8.75 \mathrm{~mm}$.

Semelhante ao macho, diferindo no que segue: olhos curta e conspicuamente ciliados, separados por um espaço de cerca de 0.40 da largura da cabeça; vita frontal com um par de cerdas cruzadas e inseridas ao nível da metade; triângulo ocelar curto, cerca de $2 / 3$ da vita frontal; cerdas frontais em número de nove pares, com os dois superiores reclinados; antena inserida acima da metade do olho; tibia I na face AV com 1-2 cerdas no terço apical; face PD com 2-3 pequenas cerdas no terço apical; tíbia II na face PV com 1-2 cerdas no terço médio; tibia III na face AD com três cerdas na metade basal e na face AV com uma série de cerdas filiformes na metade apical; face PD com 4-5 cerdas em toda a face.

Ovipositor: (foi dissecado um exemplar proveniente de Punta Arenas, Chile). Ovipositor longo, tubular, cerca de 1.5 vezes o comprimento do abdome; sem microtriquias; tergito VII estreito (fig. 27).

Material examinado: CHILE. Magallanes: Punta Arenas, 1 macho, 1 fêmea, 9.I.1951, R. BARIENTOS (USNM); ibidem, 2 machos, 5 fêmeas, 9-15.I.1966, FLINT \& CEKALOVIC (USNM); ibidem, 1 macho, 10-15.I.1966, FLINT \& CEKALOVIC (USNM); ibidem, 2 fêmeas, 11.I.1966, FLINT \& CEKALOVIC (USNM). ARGENTINA. Santa Cruz: Lago Argentino (La Cristina), 1 fêmea, 30.I.1953, WILLINK, (IML).

Distribuição geográfica (fig. 82): CHILE (Magallanes); ARGENTINA (Santa Cruz, Terra do Fogo).

Palpibracus separatus (Malloch)

(Fig. 37, 40-42, 68, 83)

Darwinomyia separata Malloch, 1934: 324 (desc. macho).

Palpibracus subtilis Albuquerque, 1951: 9 (desc. macho/fêmea); Pont, 1972:

17 (cat.).

Palpibracus separatus; Pont, 1972: 17 (cat.).

Darwinomyia separatus; Albuquerque, 1979: 326 (sic; pcat.). 
Material-tipo: Holótipo macho de D. separata, etiquetado: "Concepcion/ ChileDec1926 (Chile), XI.1926)/R \& Shannon"; "Holotype No./49766)U.S. N.M. (etiqueta vermelha)"; "Darwinomyia/separata/type/det. JRMalloch (etiqueta manuscrita de Malloch)" (USNM). Está em bom estado; quase todas as cerdas estão intactas; falta a perna anterior esquerda; o abdome está dissecado, acondicionado em tubinho com glicerina.

Holótipo macho de P. subtilis, etiquetado: "CHILE I-1925/Perales/P.Flanimo Ruiz"; "Perales/I-25 (etiqueta manuscrita)"; HOLOTIPO (etiqueta vermelha); "Palpibracus/subtilis sp.n./D. Albuquerque det. (etiqueta manuscrita do Albuquerque)" (MNRJ). Está em razoável estado com a quetotaxia quase completa; pernas anteriores e médias direitas coladas em uma etiqueta triangular; falta a perna média esquerda; asa esquerda em parte destruida; segmentos genitais montados em uma lâmina em Bálsamo do Canada (LOPES et alii, no prelo).

Alótipo de P. subtilis, etiquetado: "CHILE I-1925/Perales/P.Flaminio Ruiz"; "Perales/I-25 (etiqueta manuscrita)", ALOTIPO (etiqueta vermelha)"; "Palpibracus/subtilis sp.n./D. Albuquerque det. (etiqueta manuscrita de Albuquerque)" (MNRJ). Está em bom estado; quetotaxia quase completa; falta a perna média esquerda e tarso posterior esquerdo. Abdome dissecado em um tubinho com glicerina.

Reconhecimento. Macho: tíbia I na face $\mathrm{V}$ com quatro cílios fortes no terço apical; tibia III na face PV com fileiras de cilios longos em toda a face; face PD com 2-3 cerdas no terço basal. Fêmea: cerdas interfrontais cruzadas ausentes; tibia II na face PV com somente uma cerda submediana.

Coloração: amarela metálica com o tórax dorsalmente apresentando uma listra larga, mediana castanho-escura; anespisterno, anepimero, metade posterior do meron e pós-noto enegrecido. Antena amarela com o terceiro artículo escurecido para o ápice. Palpo amarelo. Lúnula amarela com polinosidade prateada. Caliptras e balancim amarelos. Asa amarelada com as veias catanho-claras. Pernas amarelas com fêmures nos terços apicais e tarsos escurecidos; pulvilos amarelados. Abdome negro com polinosidade cinzenta.

Descrição.-Macho: 7,67-8.33 mm. Asa: 8.00-9.08 mm.

Cabeça: olhos fortemente unidos, com numerosos cilios longos, afastados por um espaço que mede à altura do ocelo anterior 0.20-0.22 mm; facetas anterointernas grandemente diferenciados. Cerdas frontais em número de 10 pares, iniciados ao nivel da lúnula e terminados abaixo do nível do ocelo anterior, os superiores fracos. Antena curta, insrida abaixo da metade do olho, com o terceiro artǐculo medindo cerca de 1.4 do segundo. Parafaciália estreita, ao nǐvel do ápice do segundo artículo antenal cerca da metade da gena ao nivel inferior do olho. Palpo falciforme.

Tórax: de $2: 4$; acr 3-4: 4-5; três cerdas umerias, duas mais fortes; uma pósumeral; uma prs; duas ia; pra forte, semelhante a npl anterior; duas sa, a posterior menor; duas psa, a posterior maior. Notopleura com duas cerdas, a posterior cerca da metade da anterior e sem cillios de revestimento. Escutelo com um par de cerdas basais; dois laterais menores que o apical; um pré-apical e um apical robusto. Uma cerda pro-episternal e 2-3 cerdas pro-epimerais. Ctps 1:3. Catepimero ciliado. Espiráculo posterior quadrangular, desenvolvido. Caliptra inferior medindo cerca de 1.4 a superior. Asa com as veias R $4+5$ e M $1+2$ divergentes 
para o ápice. Coxa I sem esporão apical. Tibia na face AV com uma cerda forte submediana; face V com 3-4 cilios fortes a partir da cerca AV; face PD com uma série de pequenas cerdas na metade apical. Tarso sem pêlos sensitivos longos; unhas e pulvilos desenvolvidos, maiores que o comprimento do pré-tarso. Fêmur II na face PV com 2-3 cerdas fortes na base. Tibia na face PV com 2-3 cerdas no terço médio; face PD com $3-4$ cerdas no terço mediano. Tarso como no par anterior; unhas e pulvilos menos desenvolvidos. Fêmur III curvo, face AV com 4-5 cerdas no terço apical. Tibia acentuadamente curva; face AD com 4-6 cerdas em toda a face; face AV com uma série de cerdas, duplicada medianamente; face PV com fileiras de cilios longos em toda a face; face PD com 2-3 cerdas no terço basal; calcar inserido no terço apical. Tarso como no par mediano.

Genitália: (foi dissecado o holótipo de Concepcion, Chile e um exemplar proveniente da Cordilheira Parral, Chile). Cercos, epândrio e surstilos (figs. 40 e 41); quinto esternito (fig. 42).

Fêmea: $7.42-7.58 \mathrm{~mm}$. Asa: $7.67-7.83 \mathrm{~mm}$.

Semelhante ao macho, diferindo no que segue: olhos curta e esparsamente ciliados, separados por um espaço cerca de 0.36 da largura da cabeça; cerdas interfrontais ausentes; triângulo ocelar longo, cerca da metade da vita frontal; cerdas frontais em número de seis pares, os dois superiores reclinados; antenas inseridas acima da metade do olho; tórax com a listra negra estreita, limitada a série de cillios acr; tibia I na face PD com 2-3 cerdas no terço apical; tỉbia II na face PV com somente uma cerda submediana; tibia III na face PD com uma cerda no limite do terço basal.

Ovipositor: (foi dissecado o alótipo de P. subtilis) ovipositor semelhante ao comprimento do abdome; microtríquias ausente (fig. 37). Este exemplar possui mal formações no ovipositor. Os tergitos não estão esclerotinizados e existe quatro espermatecas piriformes. Infelizmente não possuo mais material fêmea desta espécie.

Material examinado: CHILE. Santiago: Las Condes; 1 macho, XI.1963, L. E. Pena (MZSP); Linares: Cord. Parral (Fdo. Macho), 1 macho, 20xi.1964, L. E. Pena (MZSP); Concepcion: (Parque Botânico Hualpén), 12 macho, x.1969, L. E. Pena (MZSP); ibidem, 2 machos, X. 1970, L. E. Pena (MZSP); Osorno: Pucatrihue, 2 fêmeas II. 1967, L. E. Pena (MZSP).

Distribuição geográfica (fig. 83): CHILE (Santiago, Linares, Concepcion, Osorno).

Palpibracus similis (Malloch)

(Figs. 38, 43-45, 84)

Darwinomyia similis Malloch, 1934: 321 (desc. macho/fêmea).

Palpibracus similis; Pont, 1972: 17 (cat.).

Material-tipo: o holótipo macho não foi estudado e provavelmente está depositado no "British Museum Natural History" (MALLOCH, 1934). 
Parátipo fêmea, etiquetado: "Bariloche/Rio Negro/AgrNov 1926 (Argentina, XI.1926) R \& EShannon"; "Paratype No/49767/U.S.N.M. (etiqueta vermelha)" (USNM). Está em bom estado, faltando a asa direita e com quase todas as cerdas intactas; o abdome dissecado está acondicionado em tubinho com glicerina.

Reconhecimento: calcar submediano. Macho: coloração geral negra com poucas regiões amarelas; fêmur II na face A com um a leve depressão mediana e pêlos de revestimento normais; face PV com 2-3 cerdas fortes na metade basal. Tỉbia III na face V e AV com uma série de cerdas em toda a face, esta mais forte no terço médio. Fêmea: vita frontal castanho-escura aveludada; tibia III na face $\mathrm{V}$ e AV com uma série de cerdas em toda a face, esta mais forte no terço médio.

Coloração: negra, com três listras polinosas cinzentas no tórax, úmero, parte da notopleura, região supra-alar, pós-alar e escutelo e maior ou menor extensão amarelo-alaranjados. Fêmeas com tórax amarelo-alaranjado com três listras negras, uma mediana larga e duaslaterais estreitas, mais visǐveis pós-suturalmente; anepimero, anepisterno, catepimero, meron e pós-noto negros; vita frontal castanho-escura aveludada. Antena castanho-escura com o primeiro, segundo e base do terceiro artículo amarelo. Palpo amarelo. Lúnula amarelada com polinosidade cinzenta. Caliptras e balancim amarelados. Asa hialina, com as veias castanhas. Pernas amareladas, com o fêmur I, exceto o ápice, fêmur II com mancha mediana inferiormente e fêmur III com mancha pré-apical, negros; tỉbias e tarsos ligeiramente escurecidos, estes mais evidentes; pulvilos amarelados. Abdome negro, com polinosidade cinzenta.

Descrição.Macho: 7.00-8.08 mm. Asa: 6.92-8.08 mm.

Cabeça: olhos fortemente unidos, com números cilios longos, afastados por um espaço que mede à altura do ocelo anterior $0.18-0.20 \mathrm{~mm}$; facetas anterointernas pouco diferenciadas. Cerdas frontais em número de 10-11 pares, iniciados ao nivel do segundo artículo antenal e terminados abaixo do nível do ocelo anterior. Antena curta, inserida abaixo da metade do olho, com o terceiro artículo medindo cerca de 1.1 vezes o segundo. Parafaciália ao nivel do ápice do segundo artículo antenal cerca de $2 / 3$ da largura gena ao nivel inferior do olho Palpo falciforme.

Tórax: de $2: 4$; acr $3: 34$; três cerdas umerais, duas mais fortes; 1 -2 pósumeral; uma prs; duas ia; pra forte, semelhante a npl anterior; duas sa, a posterior menor; duas psa, a posterior maior. Notopleura com duas cerdas, a anterior cerca de 1,5 vezes a posterior, e sem cilios de revestimento. Escutelo com um par de cerdas basais; dois laterais, o anterior mais forte e um apical robusto. Uma cerda pro-episternal e duas pro-epimerais. Ctps 1:2-3, a posterior maior. Catepimero com 7-8 cílios. Espiráculo posterior médio, ovalado. Caliptra inferior medindo cerca de 1.9 a superior. Asa com as veias $\mathrm{R} 4+5$ e M $1+2$ divergentes para o ápice. Coxa I com esporão apical. Tibia na face AV com três cerdas finas na metade apical, a submediana maior; face V com dois cilios longos; face PD com 1-2 pequenas cerdas. Unhas e pulvilos longos, semelhante ao comprimento do pré-tarso. Fêmur II na face A com uma leve depressão mediana e pélos de revestimento mormais; face AV com uma série de cerdas longas maiores na metade basal, decrescendo para o ápice; face PV com 2-3 cerdas fortes no terço basal 
e uma série de 6.7 cerdas finas no terço apical. Tỉbia na face PD com quatro cerdas em toda a face; face P e PV com três cerdas no terço médio. Unhas e pulvilos curtos, menores que o comprimento do pré-tarso. Fêmur III discretamente curvo; face $\mathrm{AV}$ com uma série de cerdas na metade basal para o ápice, as primeiras pequenas e finas, duplicando-se em parte ventralmente e aumentando para o ápice. Tibia curva; face V e AV com uma série de cerdas em toda a face, esta mais forte no terço médio; face $\mathrm{AD}$ com uma série de cinco cerdas em toda a face; face P e PV com uma série de cerdas filiformes na metade basal; face PD com cinco cerdas em toda a face, o calcar inserido submedianamente. Tarso como no par mediano.

Genitália: (foi dissecado um exemplar proveniente de Las Trancas, Cord. Chillán, Chile). Cercos, epândrio e surstilos (figs. 43 e 44); quinto esternito (fig. 45).

\section{Fêmea: $7.17 \mathrm{~mm}$. Asa: $7.75 \mathrm{~mm}$.}

Semelhante ao macho, diferindo no que segue: olhos curta e conspiculamente ciliados, separados por um espaço de cerca de 0.33 de largura da cabeça; vita frontal com um par de cerdas cruzadas e inseridas ao nível da metade; triângulo ocelar curto, com cerca de $2 / 3$ da vita frontal; cerdas frontais em número de nove pares, os dois superiores reclinados; antena insrida acima da metade do olho, tibia I na face AV com uma cerda submediana; face PD com 34 pequenas cerdas na metade apical; tíbia II na face AD com 2-3 cerdas no terço médio; face P com três cerdas e face PV com uma medianamente; tibia III na face AD com três cerdas na metade basal e AV com 3-4 cerdas fracas no terço médio; face PD com 4-5 cerdas em toda a face, o calcar inserido submedianamente.

Ovipositor: (foi dissecado o parátipo fêmea); ovipositor longo, tubular, cerca de 1.5 vezes maior que o comprimento do abdome; sem microtríquias; tergito VII estreito (fig. 38).

Material examinado: CHILE. Nuble: Las Trancas (Cordilheira Chillán), 1 macho, II.1969, L. E. Pena (DZUP). ARGENTINA. Neuquen. San Martin de los Andes, 1 macho, 11.XII.1946 (IML).

Distribuiç̧ão geográfica (fig. 84): CHILE (Nuble), ARGENTINA (Neuquen, Rio Negro).

\section{Palpibracus spicatus (Malloch)}

(Figs. 39, 46-48, 69, 85)

Darwinomyia spicata Malloch, 1934: 329 (desc. macho/fêmea).

Palpibracus spicatus; Pont, 1972: 17 (cat.).

Material-tipo: o holótipo macho não foi estudado e provavelmente está depositado no "British Museum Natural History" (MALLOCH, 1934).

Parátipo macho, etiquetado: "Bariloche/Rio Negro/Agr-Nov1926 (Argentina, XI.1926)/R \& EShannon"; "Paratype No/49770/U.S.N.M. (etiqueta vermelha)" (MNRJ). É um exemplar não totalmente esclerotinizado; está em bom estado com quase todas as cerdas intactas; a asa esquerda está quebrada no bordo costal. 
Reconhecimento: coloração amarela com uma listra negra, estreita, mediana. Macho: tibia III na face AD com sete cerdas em toda a face, maiores medianamente: face $\mathrm{AV}, \mathrm{V}$ e $\mathrm{P}$ com séries de cerdas longas e finas nos 2/3 apicais, menores para o ápice. Fêmea: vita frontal castanho-escura, avermelhada anteriormente no centro e sem cerdas cruzadas.

Coloração: amarela, com o tórax apresentando uma listra negra, estreita, mediana dorsal, que ultrapassa pouco as acr. Escutelo amarelo-claro; catepisterno, meron e catepimero negros. Vita frontal das fêmeas castanho-escura aveludada, avermelhada anteriormente no centro. Antena castanho-escura com o segundo artículo pouco mais claro. Palpo castanho-escuro. Lúnula amarela, com polinosidade cinzenta. Caliptras e balancim amarelas, este com o capitelo escurecido. Asa amarelada com as veias castanho-claras. Pernas castanho-escuras, com as tibias pouco mais claras; pulvilos amarelados. Abdome negro com discreta polinosidade cinzenta.

Descrição. Macho: 5 .83-6.25 mm. Asa: 6.67-6.83 mm.

Cabeça: olhos fortemente unidos, com esparsos cilios curtos, afastados por um espaço que mede à altura do ocelo anteior $0.14-0.16 \mathrm{~mm}$; facetas anterointernas alargadas. Cerdas frontais em número de $7-8$ pares, iniciados ao nìvel da lúnula e terminados abaixo do nivel do ocelo anterior, os superiores mais fracos. Antena inserida abaixo da metade do olho, com o terceiro artículo medindo cerca de 1.3 vezes o segundo. Parafaciália larga, ao nivel do ápice do segundo artículo antenal cerca de $2 / 3$ da largura da gena ao nivel inferior do olho. Palpo falciforme.

Tórax: de 2:4; acr 3-3; 2-3; duas cerdas umerais; uma pós-umeral; uma prs; duas ia; pra forte, semelhante a npl anterior; duas sa, a posterior mais fraca; duas psa, a posterior mais forte. Notopleura com duas cerdas, a posterior cerca da metade da anterior. Escutelo com um par de cerda basal fraca; dois laterais menores que o apical; um pré-apical filiforme e um apical robusto. Uma cerda pro-episternal e uma pro-epimeral. Ctps 1:3. Catepimero nu. Espiráculo posterior médio, ovalóide. Caliptra inferior medindo cerca de 1.3 vezes a superior. Asa com as veias $\mathrm{R} 4+5$ e M $1+2$ divergentes para o ápice. Coxa I com esporão apical. Tibia na face AV com uma cerda submediana; face PD com 2-3 cerdas pequenas no terço apical. Tarso sem pêlos sensitivos longos; unhas e pulvilos pequenos, menores que o comprimento do pré-tarso. Fêmur II na face A com uma depressão mediana e cílios de revestimento normais; face A com 3-4 pequenos espinhos fortes no terço apical seguidas inferiormente por duas séries de pequenos espinhos mais fracos até a metade apical; face PV com uma série de cerdas finas e longas em toda a face, mais robusta para o ápice; face $\mathrm{V}$ com cilios longos na metade basal. Tibia na face $\mathrm{AD}$ com sete cerdas em toda a face, maiores medianamente; face $\mathrm{AV}, \mathrm{V}, \mathrm{PV}$ e $\mathrm{P}$ com séries de cerdas longas e finas nos $2 / 3$ apicais, menores para o ápice; face PD, frequentemente com 1-2 cerdas pequenas no terço basal; calcar forte inserido no limite do terço apical. Tarso como no par anterior.

Genitália: (foi dissecado um exemplar de Dalcahue, I. Chiloé, Chile). Cercos, epândrio e surstilos (figs. 46 e 47); quinto esternito (fig. 48).

Fêmea: 6.25-6.33 mm. Asa: 6.33-6.50 mm. 
Semelhante ao macho diferindo no que segue: olhos quase nus, separados por um espaço de cerca de 0.37 da largura da cabeça; vita frontal sem cerdas cruzadas; triângulo ocelar longo, cerca da metade da vita frontal; cerdas frontais em número de 6-7 cerdas, os dois superiores reclinados; antenas inseridas acima da metade do olho; fêmur II na face A com uma série de 7-8 cerdas na metade basal e duas pré-apicais inseridas obliquamente; tibia III na face AV com 3-5 cerdas na metade apical; face PD com apenas o calcar.

Ovipositor: (foi dissecado um exemplar proveniente de Dalcahue, I. Chiloé, Chile e um exemplar de El Coigual, cord. Curicó, Chile). Ovipositor tubular, pouco menor que o comprimento do abdome; sem microtríquias; tergito VII estreito (fig. 39).

Variação: foi encontrado um exemplar de Dalcahue, Chile com apenas três cerdas de pós-suturais. Não foi constatada qualquer outra diferença significativa.

Material examinado: CHILE. Santiago, 1 fêmea, 20.III.1967, L. E. Peña (MNRJ). Colchaqua: El Manzano, 2 machos,XI.1951, Kuschel (MNRJ). Curicó: El Coigual (Cord. Curicó), 1 fêmea, I.1964, L. E. Pena (MZSP). Osorno: Pucatrihue, 3 fêmeas,II.1967, L. E. Pena (MZSP); Termas Rio Blanco (Cura Contin), 1 fêmea, $28 . I I I .1938$ (USNM). Chiloé: Dalcahue, 1 macho, 15 fêmeas, I.1962, L. E. Peña (MZSP); ibidem, 2 machos, 7 fêmeas, IV.1968, L. E. Peña (MZSP).

Distribuição geográfica (fig. 85): CHILE (Santiago, Colchagua, Curicó, Osorno, Chiloé) e ARGENTINA (Rio Negro).

\section{Palpibracus trivittatus (Malloch)}

(Figs. 49, 52-54, 70-86)

Darwinomyia trivittata Malloch, 1934: 333 (macho/fêmea).

Anacanthosphys trivittata; Enderlein, 1935: 244 (desc.).

Palpibracus trivittatus; Pont, 1972: 17 (cat.).

Material-tipo: o holótipo não foi examinado e provavelmente está depositado no "British Museum Natural History" (MALLOCH, 1934).

Parátipo macho, etiquetado: "Correntoso/Rio Negro/Arg-Nov1926 (Argentina, XI.1926)/R \& EShannon"; "Paratype No./49774/U.S.N.M. (etiqueta vermelha)"; Darwinomyia/trivittata/Paratype det. JRMalloch (etiqueta manuscrita do Malloch)" (USNM). Está em boa condição com todas as cerdas intactas.

Três parátipos machos, etiquetados: "Bariloche/Rio Negro/ArgNov1926 (Argentina, XI.1926)R \& EShannon"; "Paratype No./49774/U.S.N. M. (etiqueta vermelha)" (USNM, MNRJ). Estão em condições piores, faltando pernas e cerdas e um exemplar falta parte da asa direita e está com o abdome dissecado acondicionado em um tubinho com glicerina.

Reconhecimento: tibia I na face AV com 1-2 cerdas filiformes medianas; face AV com duas cerdas no terço apical.

Coloração: amarela com o tórax apresentando três listras negras separadas ou fundidas, a central sempre atingindo o escutelo; pleuras inferiores negras. Vita frontal nos machos castanho-claro; nas fêmeas castanho-escura com áreas fortemente avermelhada. Antena castanho-escura com o ápice do segundo arti- 
culo mais claro. Palpo castanho-escuro com a base pouco mais claras. Lúnula amarela com polinosidade prateada. Caliptras e balancim amarelos. Asa amarelada com as veias castanho-claras. Pernas castanho-escuras; pulvilos amarelados. Abdome negro com discreta polinosidade cinzenta.

Descrição. Macho: $5.83-5.83 \mathrm{~mm}$. Asa: 6.25-6.33.

Cabeça: olhos fortemente unidos, com numerosos cillios longos afastados por um espaço que mede à altura do ocelo anterior 0.10-0.12 $\mathrm{mm}$; facetas anterointernas dilatadas. Cerdas frontais em número de $9-12$ pares, iniciados ao nível da lúnula e terminados abaixo do ocelo anterior. Antena inserida abaixo da metade do olho, com o terceiro artículo medindo cerca de 1.3 vezes o segundo. Parafaciália estreita, ao nivel do segundo artículo antenal cerca da metade da gena ao nǐvel do olho. Palpo clavado (longos para o ápice).

Tórax: dc 2:4; acr 2:3, três cerdas umerais, duas mais fortes; uma pós-umeral; uma prs; duas ia; pra forte, semelhante a npl anterior; duas sa, a posterior menor; duas psa, a posterior maior. Notopleura com duas cerdas, a posterior cerca da metade da anterior e sem cilios de revestimento. Escutelo com um par de cerdas basais; dois laterais menores que o apical; um pré-apical fraco e um apical robusto. Uma cerda pro-episternal e duas pro-epimeral. Ctps 1:2, com abundantes cílios longos de revestimento. Catepimero nu. Espiráculo posterior oval, desenvolvido. Caliptra inferior medindo cerca de 1.3 vezes a superior. Asa com as veias R $4+5$ e M $1+2$ paralelas para o ápice. Coxa I sem esporão apical. Tibia na face $\mathrm{V}$ com 1-2 cilios longos medianos e AV com duas cerdas no terço apical; face PD com um pequena cerda no terço apical. Tarso sem cillios sensitivos longos; unhas e pulvilos pequenos, menores que o comprimento do pré-tarso. Fêmur II na face PV com uma série de cerdas ciliformes, maiores na base; faces $\mathrm{AV}$ e V com cerdas semelhantes ao da face PV, porém menores. Tỉbia na face PV com 2-3 cerdas; face PD com $4-5$ cerdas. Tarso como no par anterior. Fêmur III na face AV com cerdas filiformes longas em toda a face, maiores na metade apical; faces $\mathrm{V}$ e PV com séries de cerdas filiformes semelhante a face AV, porém menores. Tỉbia na face $\mathrm{AD}$ com 6-7 cerdas em toda a face; face $\mathrm{AV}, \mathrm{V}$ e PV com 2-3 cilios fortes no terço basal; face PD com o calcar forte, inserido no terço apical. Tarso conıo no par anterior.

Genitália: (foi dissecado um parátipo proveniente de Angol, Chile e um parátipo proveniente de Bariloche, Argentina). Cercos, epândrio e surstilos (figs. 52 e 53); quinto esternito (fig. 54).

Fêmea: 5.83-6.08 mm. Asa: 6.50-6.67 mm.

Semelhante ao macho diferindo no que segue: olhos curta e esparsamente ciliados, separados por um espaço de cerca de 0.34 a largura da cabeça; vita frontal com cerdas cruzadas e inseridas no nivel da metade; triângulo ocelar longo, cercá de $2 / 3$ da vita frontal; cerdas frontais em número de 6-7 pares, os dois superiores reclinados; antenas inseridas acima da metade do olho; tỉbia I na face PD com duas pequenas cerdas no terço apical.

Ovipositor: (foi dissecado um exemplar proveniente de Angol, Chile). Ovipositor semelhante ao comprimento do abdome; microtíquias ausentes; reticulações pouco desenvolvidas somente nas regiões laterais do oitavo e sétimo segmento; tergito VII estreito (fig. 49). 
Variação: as listras torácicas negras podem estar frequentemente separadas ou fundidas. Neste caso, ocupa quase toda a região dorsal do tórax.

Material examinado: CHILE: Linares: Cord. Parral (Fdo. Macho), 3 machos, 1 fêmea, 20.XI.1964, L. E. Peña (MZSP). Malleco: Angol, 1200 m, 1 macho, 5 fêmeas, 11.III.1929 (USNM).

Distribuição geográfica (fig. 86): CHILE (Linares, Malleco), ARGENTINA (Rio Negro).

\section{Palpibracus univittatus (Bigot) \\ (Figs. 50, 55-57, 71, 87)}

Limnophora univittata Bigot, 1857: 303 (desc. fêmea); Malloch, 1928: 313 (cit.).

Aricia univittata; Stein, 1907: 290 (rdesc. fêmea).

Darwinomyia univittata; Malloch, 1928: 314 (chave, cit.); MALLOCH, 1934: 329 (partim, rdesc. fêmea); Snyder, 1957: 489 (partim, desc. macho/fêmea). Phaonia univittata; Seguy, 1937: 338 (cat.).

Palpibracus univittatus; Pont, 1972: 17 (cat.).

Material-tipo: a série-tipo, incluindo o holótipo, não foi examinada e está depositada na coleção Bigot (SNYDER, 1957: 489).

Reconhecimento: amarela com listra torácica negra, estreita; antena castanho-escura, com o primeiro e segundo artículos amarelos. Macho: fêmur II na face A com uma depressão mediana. e 7-8 pequenos espinhos fortes no terço apical; tibia III levemente curvada e na face AV e PV com uma série de pequenas cerdas em toda a face, estas mais fracas e maiores no quinto apical. Fêmea: vita frontal amarelada, levemente escurecida posteriormente e sem cerdas cruzadas.

Coloração: amarela com o tórax apresentando uma listra negra, mediana, estreita - que pouco ultrapassa as acr. Escutelo castanho-claro. Catepisterno, abaixo das ctps, meron, catepimero e pós-noto negros. Vita frontal das fêmeas amarelada, levemente escurecida posteriormente. Antena castanho-escura, com o primeiro e segundo artículo e base do terceiro amarelo. Palpo amarelo. Lúnula amarelada, com polinosidade cinzenta. Caliptras e balancim amarelos, aqueles mais claros. Asa amarelada com as veias castanho-claras. Pernas castanho-escuras, com as tibias pouco mais claras; pulvilos amarelados. Abdome negro com discreta polinosidade cinzenta.

Descrição. Macho: 6.33-6.50 mm. Asa: 7 08-7.25 mm.

Cabeça: olhos fortemente unidos, com espaços cilios curtos, afastados por um espaço que mede à altura do ocelo anterior 0.14-0.16 mm; facetas anterointernas alargadas. Cerdas frontais em número de $8-9$ pares, iniciados ao nivel da lúnula e terminados abaixo do nivel do ocelo anterior, os superiores mais fracos. Antena inserida acima da metade dos olhos, com o terceiro artículo medindo cerca de 1.3 o segundo. Parafaciália ao nivel do segundo artículo antenal cerca de $2 / 3$ da largura da gena ao nível inferior do olho. Palpo falciforme.

Tórax: de 2:4; acr 3:3-4; duas cerdas umerais; uma pós-umeral; uma prs; duas ia; pra forte, maior que a npl anterior; duas sa, a posterior fraca; duas 
psa, a posterior mais forte. Notopleura com duas cerdas, a posterior cerca da metade da anterior e sem cilios de revestimento. Escutelo com um par de cedas basais fracos; dois laterais, o anterior semelhante ao apical; um pré-apical fracos; dois laterais, o anterior semelhante ao apical; um pré-apical fracoe um apical robusto. Uma cerda pro-episternal e uma pro-epimeral. Ctps 1:3. Catepimero nu. Espiráculo posterior, médio, ovalóide. Caliptra inferior medindo cerca de 1.6 a superior. Asa com as veias $\mathrm{R} 4+5$ e $\mathrm{M} 1+2$ paralelas para o ápice. Coxa I com esporão apical. Tỉbia na face AV com uma cerda submediana; face PD com uma pequena cerda no terço médio; face $\mathrm{V}$ com 0-1 cillio submediano. Tarso sem pélos sensitivos longos; unhas e pulvilos grandes, semelhante ao comprimento do pré-tarso. Fêmur II concavo, na face AV com uma cerda submediana; face PD com uma pequena cerda no terço médio; face $\mathrm{V}$ com 0-1 cillio submediano. Tarso sem pêlos sensitivos longos; unhas e pulvilos grandes, semelhante ao comprimento do pré-tarso. Fêmur II concavo, na face A com uma depressão mediana e cillios de revestimento normais; face $\mathrm{A}$ com 7.8 pequenos espinhos fortes no terço apical; face PV e V com séries de cerdas filiformes na metade basal, esta com 7-8 cerdas fortes no terço apical. Tỉbia na face PD com três cerdas e AV com 2-3. Unhas e pulvilos pequenos, menores que o comprimento do pré-tarso. Fêmur III na face AV com somente uma cerda forte no terço apical. Tibia levemente curva; face AV com $2-4$ cerdas em toda a face, a mediana mais forte; face AV com uma série de pequenas cerdas em toda a face; face PD com o calcar forte e inserido no limite do terço apical. Tarso com o par mediano.

Genitália: (foi dissecado um exemplar proveniente de Pucatrihue, Osorno, Chile). Cercos, epândrio e surstilos (figs. 55 e 56); quinto esternito (fig. 57).

Fêmea: $6.42 \mathrm{~mm}$. Asa: $6.67 \mathrm{~mm}$.

Semelhante ao macho, diferindo no que segue: olhos quase nus, separados por um espaço de cerca de 0.40 da largura da cabeça; vita frontal sem cerdas cruzadas; triângulo ocelar longo, cerca da metade da vita frontal; cerdas frontais em número de sete pares, os dois superiores reclinados; fêmur II na face A com uma série de oito cerdas na metade basal e uma pré-apical; tibia na face AV com apenas uma cerda mediana; fêmur III levemente curvo; tibia na face AV com 1-3 cerdas na metade apical.

Ovipositor: (foi dissecado um exemplar proveniente de Dalcahue, Chile). Ovipositor tubular, semelhante ao comprimento do abdome; sem microtríquias; tergito VII estreito (fig. 50).

Material examinado: CHILE. Osorno: Pucatrihue, 2 machos, II.1967, L.E. Peña (MZSP). Chiloé: Dalcahue, I. Chiloé, 1 fêmea, I.1962, L. E. Peña (MZSP). Distribuição geográfica (fig. 87): CHILE (Osorno, Chiloé).

Palpibracus veneris (B igot)

(Figs. 51, 58-60, 72, 88)

Helomyza veneris Bigot, 1888: 34 (desc. fêmea).

Darwinomyia veneris; Malloch, 1934: 325 (desc. macho/fêmea). 
Darwinomyia atricornis Malloch, 1934: fig. 56b (publicada somente na legenda da figura).

Catantigymnus veneris; Enderlein, 1935: 244 (desc.).

Palpibracus veneris; Pont, 1972: 17 (cat.).

Material-tipo: o holótipo fêmea de P. veneris não foi examinado e provavelmente está depositado no "Museum National d'Historie Naturelle" em Paris (MALLOCH, 1934:325).

Três parátipos machos de D. atricornis Malloch, etiquetados: "Casa Pangue/Llanquihue/Chile Dec1926 (XII.1926)R \& EShannon"; "Paratype No./ 49775/U.S.N.M. (etiqueta vermelha) (USNM), MNRJ). Estão em estado razoável; faltam algumas pernas e parte do abdome;

Dois parátipos fêmeas de D. atricornis Malloch, etiquetados: "Bariloche/ Rio Negro/AgrNov1926 (Argentina, XI.1926)/R \& EShannon”; "Paratype No./49775/U.S.N.M. (etiqueta vermelha) (USNM). Estão em estado ruim: um exemplar está com o tegumento bastante sujo, faltando as pernas médias, a direita colada na etiqueta de procedência e o abdome está dissecado acondicionado em um tubinho com glicerina; um outro exemplar não está totalmente esclerotinizado;

Um parátipo fêmea de D. atricornis Malloch, etiquetado: "Correntoso/Rio Negro/AgrNov1926 (Argentina, XI.1926)/R \& EShannon"; "Paratype No. 49775/U.S.N.M. (etiqueta vermelha) (USNM). Está em bom estado, com a quetotaxia completa, faltando apenas a antena esquerda; é um exemplar não totalmente esclerotinizado.

Este material está na coleção do USNM, com os rótulos de tipos do Diptera of Patagonia and South Chile. Provavelmente J. R. Malloch verificou posteriormente a igualdade de $\mathbf{D}$. atricornis com $\mathbf{D}$. veneris (Bigot) e não retirou os rótulos de tipos da coleção e esquecendo também de retirar a legenda da figura (MALLOCH, 1934: 320).

Reconhecimento: cabeça larga, com o diâmetro igual a altura; tibia II na face PV nua. Macho: cerdas frontais limitadas a metade anterior; tibia III na face AV com uma série de cerdas em toda a face, maiores para o ápice.

Coloração: coloração geral, metálica com polinosidade cinzenta; tórax com uma listra mediana negra limitada às acr, que atinge o escutelo; frequentemente com dois esboços de listras castanho-escuras que coincidem com as dc. Vita frontal castanho-escura com regiões amareladas. Antena e palpo castanho-escuros. Lúnula com polinosidade prateada. Caliptras e balancim amarelos. Asa amarela$\mathrm{da}$ com as veias castanhas. Pernas castanho-escuras com as tibias mais claras; pulvilos amarelados. Abdome negro com polinosidade cinzenta.

Descrição. Macho: 7.50-8.58 mm. Asa: 8.58-8.83 mm.

Cabeça: olhos fortemente unidos, com esparsos cilios curtos afastados por um espaço que mede à altura do ocelo anterior $0.10-0.12 \mathrm{~mm}$; facetas anterointernas grandemente diferenciadas. Cabeça larga, com o diämetro igual a altura. Cerdas frontais em número de sete pares limitados a metade anterior. Antena longa atingindo o epǐstoma, inseridas ao nivel da metade do olho; terceiro artículo medindo cerca de 1.7 o segundo. Parafaciália ao nĩvel do ápice segundo artículo antenal cerca de $2 / 3$ da gena ao nivel inferior do olho. Palpo falciforme. 
Tórax: de $2: 4$; acr $2: 7$; duas cerdas umerais; uma pós-umeral; uma prs; duas ia; pra forte, semelhante a $\mathrm{npl}$ anterior; duas sa, a posterior menor; duas psa, a posterior maior. Notopleura com duas cerdas semelhante entre si e sem cilios de revestimento. Escutelo com um par de cerda basais; dois laterais menores que o apical; um pré-apical fraco e um apical robusto. Uma cerda pro-episternal e uma pro-epimeral. Ctps 1:1. Espiráculo posterior quadrangular, desenvolvido. Caliptra inferior medindo cerca de 1.8 a superior. Asa com as veias R $4+5$ M $1+2$ paralelas para o ápice. Coxa I sem esporão apical. Tỉbia I inerme. Tarso sem pêlos sensitivos longos; unhas e pulvilos pequenos, menores que o comprimento do pre-tarso. Femur II nas face AV, PV e V com cilos longos nos $2 / 3$ basais, notadamente os $\mathrm{V}$. Tibia na face $\mathrm{P}$ com 3.4 cerdas no terço médio; face PV nua. Tarso como no par anterior. Fêmur III na face AV com 3-4 cerdas fortes e espaçadas no terço apical. Tỉbia na metade apical; face PV com uma série de cerdas em toda a face maiores para o ápice; face PD com calcar no quarto apical. Tarso como no par anterior.

Genitália: (foi dissecado um parátipo de $\mathbf{P}$. atricornis proveniente de Casa Pangue, Llanquihue, Chile). Cercos, epândrio e surstilos (figs. 58 e 59); quinto esternito (fig. 60).

Fêmea: 5.50-6.92 mm. Asa: 7.75-8.33 mm.

Semelhante ao macho, diferindo no que segue: olho curta e esparsamente ciliado, separados por um espaço de cerca de 0.35 da largura da cabeça; vita frontal com cerdas cruzadas e inseridas ao nivel da metade; triângulo ocelar longo, cerca da metade da vita frontal; cerda frontais em número de 5.7 pares, os dois superiores reclinados; antena inseridas acima da metade do olho.

Ovipositor: (foi dissecado um parátipo de $\mathbf{P}$. atricornis proveniente de Bariloche, Rio Negro, Argentina). Ovipositor menor que o comprimento do abdome; microtríquias ausente; tergito VII largo (fig. 51).

Material examinado: CHILE. Nuble: Las Trancas (Refúgio Andino, Volcán de Chilian), 3 machos, 1 fêmea, I.1970, L. E. Peña (MZSP). Llanquihue: Casa Pangue, 1 macho, 4-10.XII.1926, F \& M. Edwards (BMNH). ARGENTINA. Rio Negro: Casa Pangue, 1 fêmea, 4-10.XII.1926, F. \& M. Edwards (BMNH).

Distribuição geográfica (fig. 88): CHILE (Nuble, Llanquihue, Chiloé, Magallanes) e ARGENTINA (Rio Negro, Terra do Fogo).

\section{AGRADECIMENTOS}

Prof. Dr. Pe. Jesus Santiago Moure (Universidade Federal do Paraná) e Prof. Dr. José Henrique Guimarães (Universidade de São Paulo) pelo incentivo, apoio, estïmulo e leitura crítica dos originais. Prof. Dr. Dalcy de Oliveira Albuquerque (Museu Nacional da Universidade Federal do Rio de Janeiro) (in memorian (1918-1982)), orientador dos meus estudos desde 1976. Pesquisadores das diversas instituições, pelo empréstimo de material. Profa. Denise Pamplona, Márcia Souto Couri e Sonia Maria Lopes (Museu Nacional-UFRJ), pela revisão critica do manuscrito. Conselho Nacional de Desenvolvimento Cientifico e Tecnológico-CNPq, pela concessão de bolsa de estudos. 

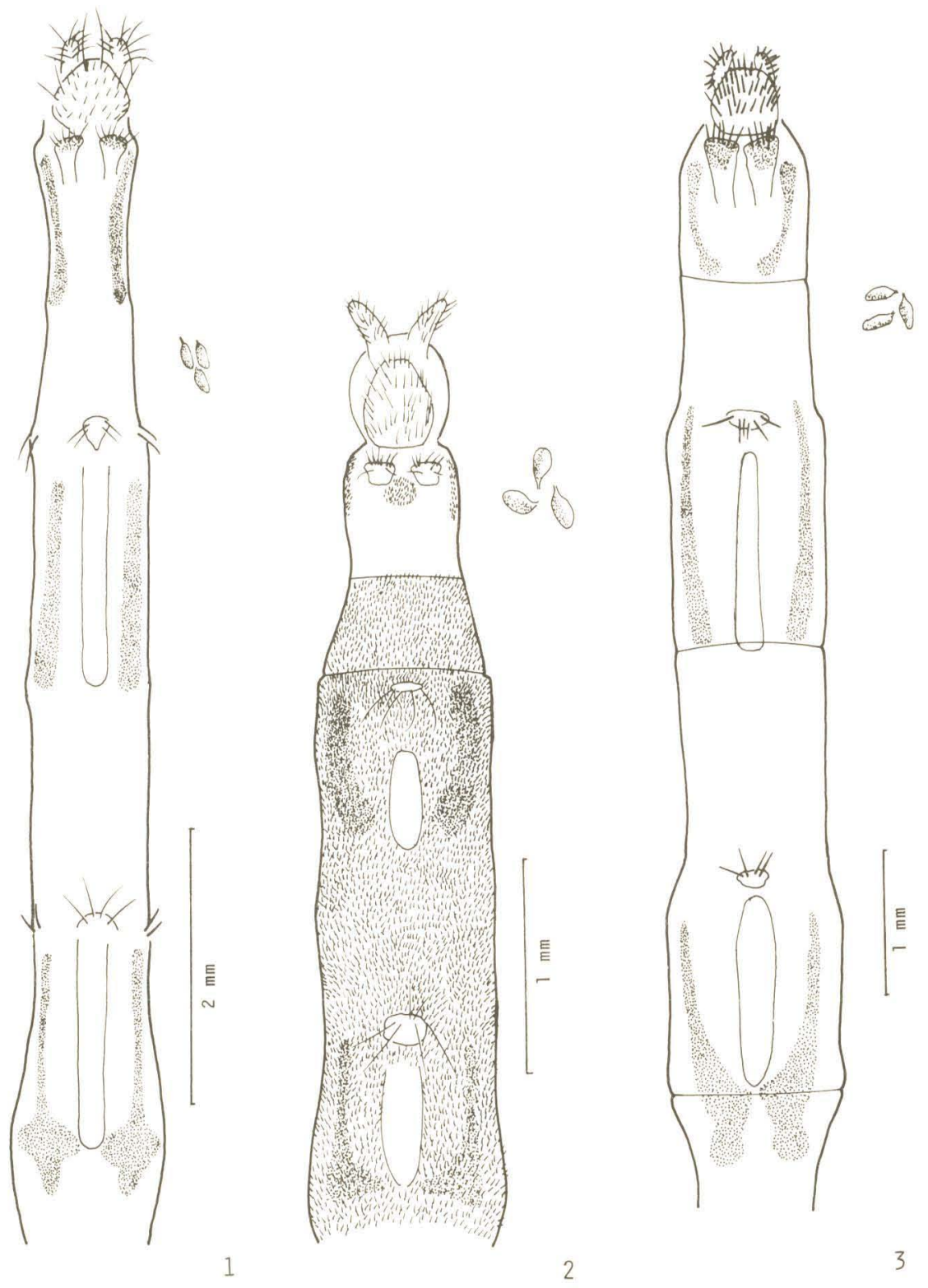

FIGS. 1-3. Ovipositores, vista ventral: 1, Palpibracus albuquerquei sp. n.; 2, P. apicalis; 3 , $P$. chilensis. 
Revta bras. Zool.
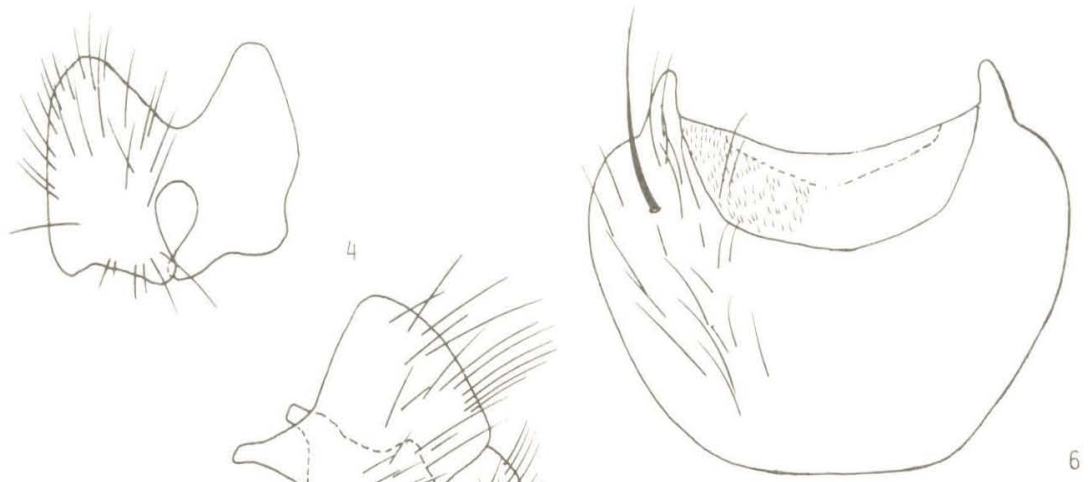

5

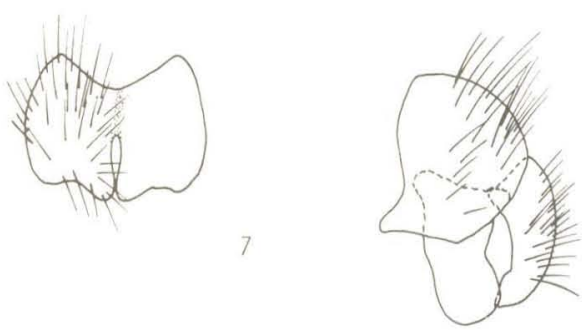

8
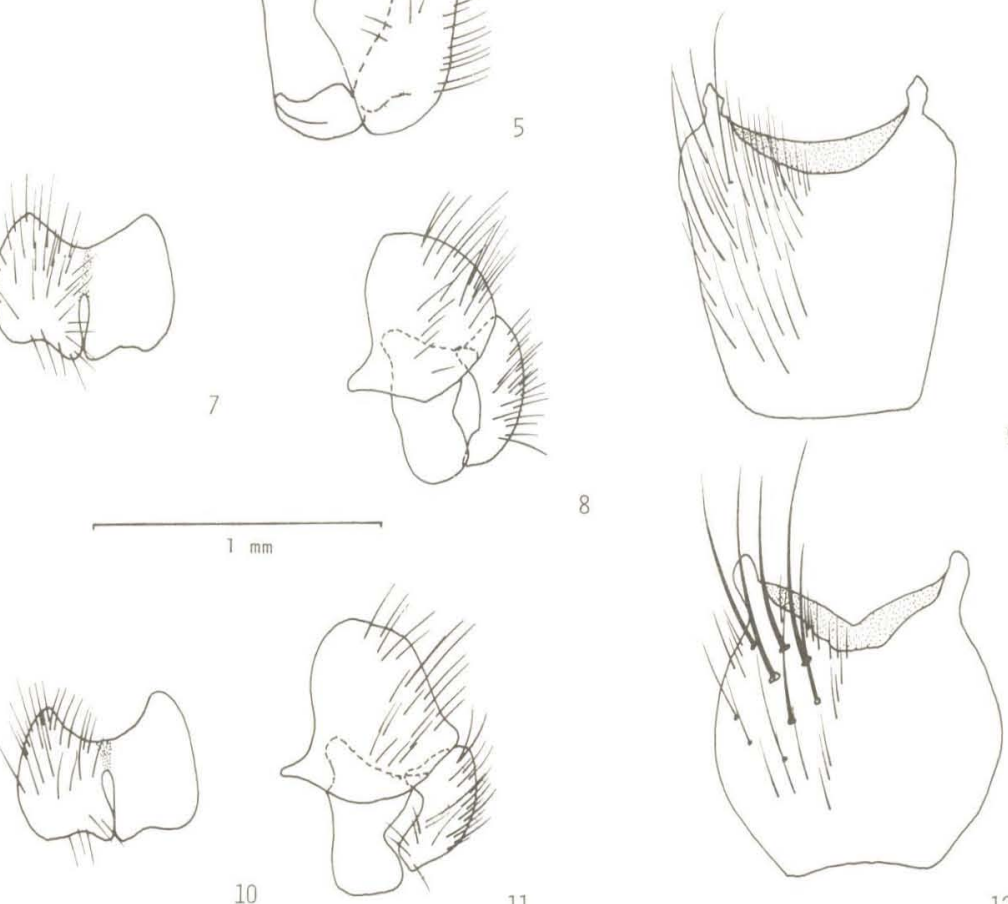

11

12

FIGS. 4-12. Palpibracus albuquerquei sp. n.: 4, cercos, vista posterior; 5, cercos, epândrio e surstilos, vista lateral; 6 , quinto esternito, vista posterior. P. apicalis: 7 , cercos, vista posterior; 8 , cercos, epândrio e surstilos, vista lateral; 9 , quinto esternito, vista posterior. P. chilensis: 10 , cercos, vista posterior; 11 , cercos, epândrio e surstilos, vista lateral; 12 , quinto esternito, vista posterior. 
Vol. 6(2), 1989
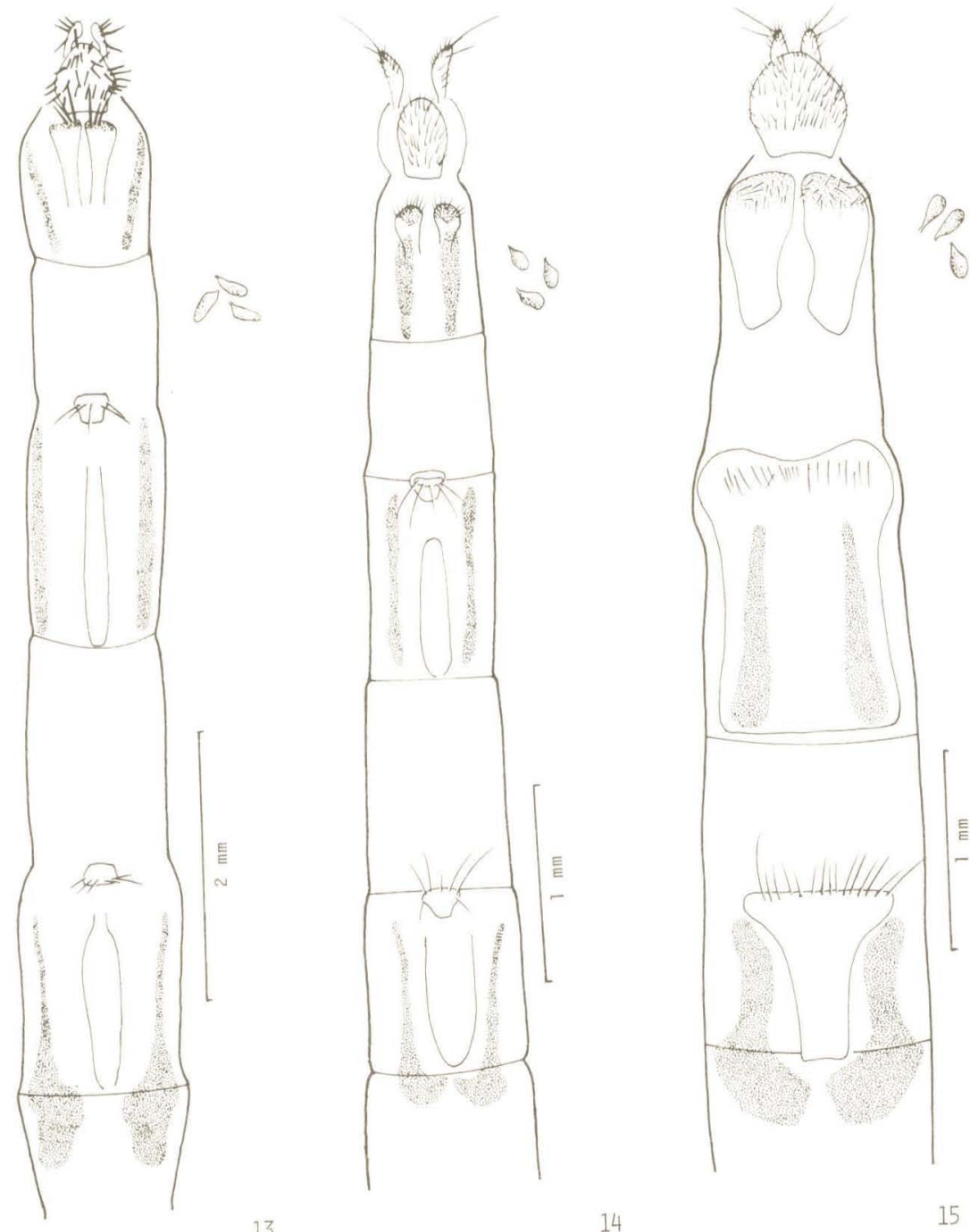

FIGS. 13-15. Ovipositores, vista ventral: 13, Palpibracus confusus; 14 , P. fasciculatus; 15 , $P$. lancifer. 
Revta bras. Zool.
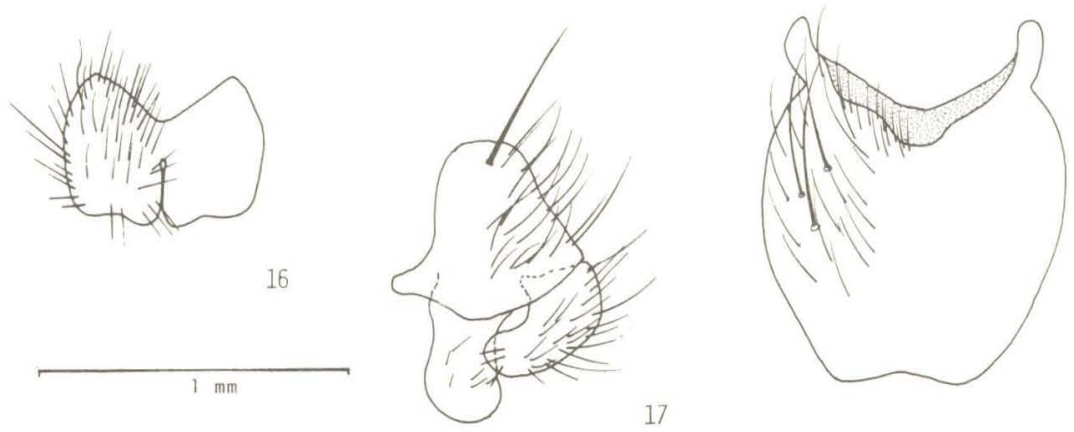

18

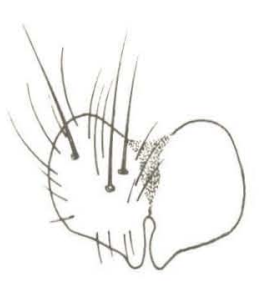

19
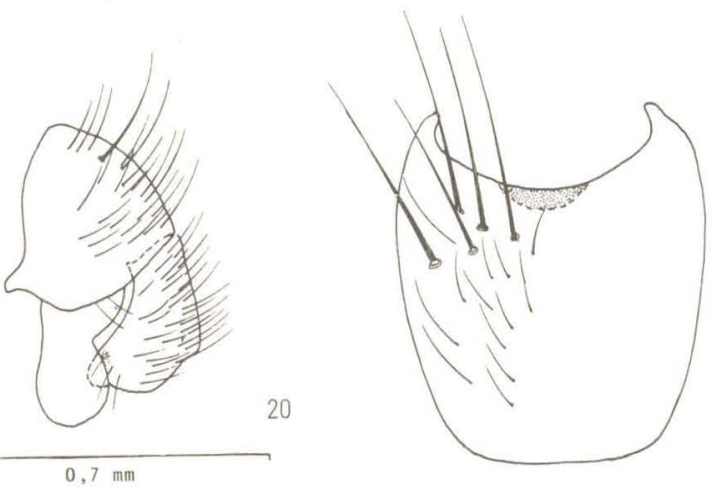

21

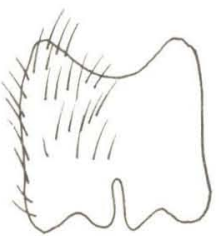

22

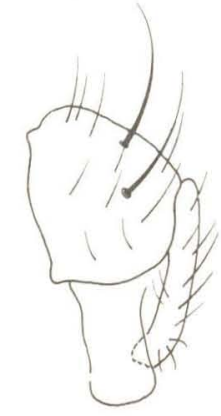

23

$0,7 \mathrm{~mm}$

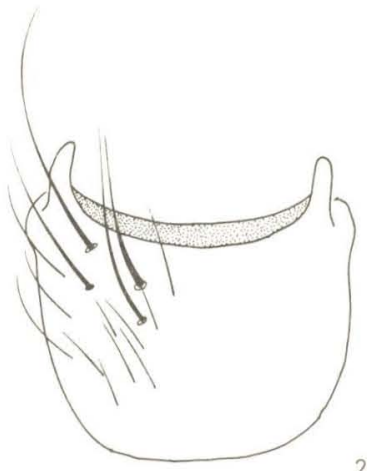

24

FIGS. 16-24. Palpibracus confusus: 16, cercos, vista posterior; 17 , cercos, epândrio e surstilos, vista lateral; 18 , quinto esternito, vista posterior. P. fasciculatus: 19 , cercos, vista posterior; 20 , cercos, epândrio e surstilos, vista lateral; 21 , quinto esternito, vista posterior. P. lancifer: 22, cercos, vista posterior; 23 , cercos, epândrio e surstilos, vista lateral; 24 , quinto esternito, vista posterior. 
Vol. 6(2), 1989

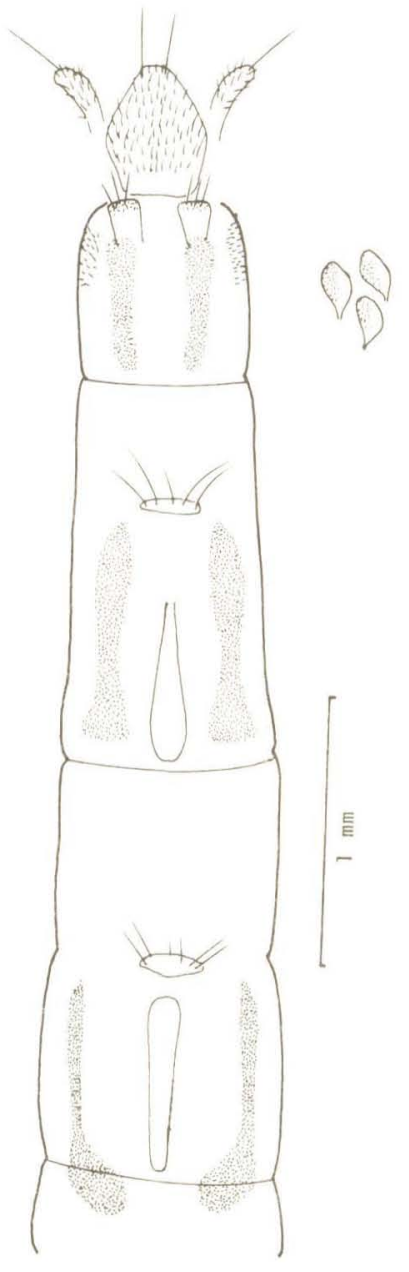

25

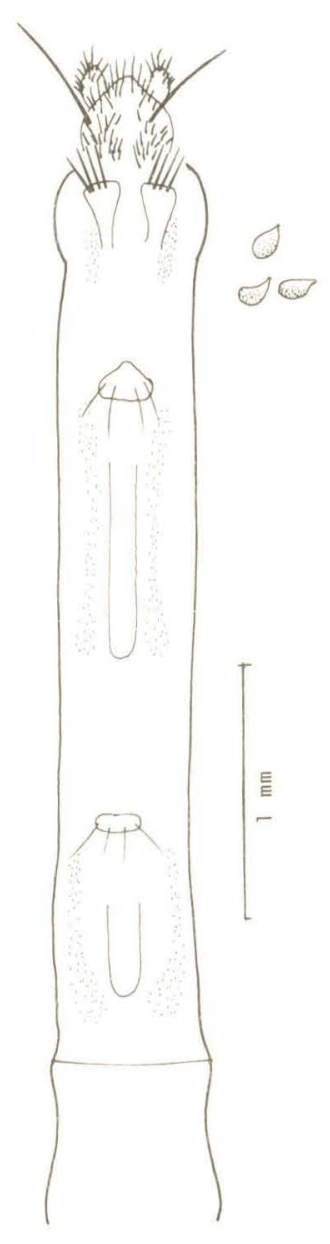

26

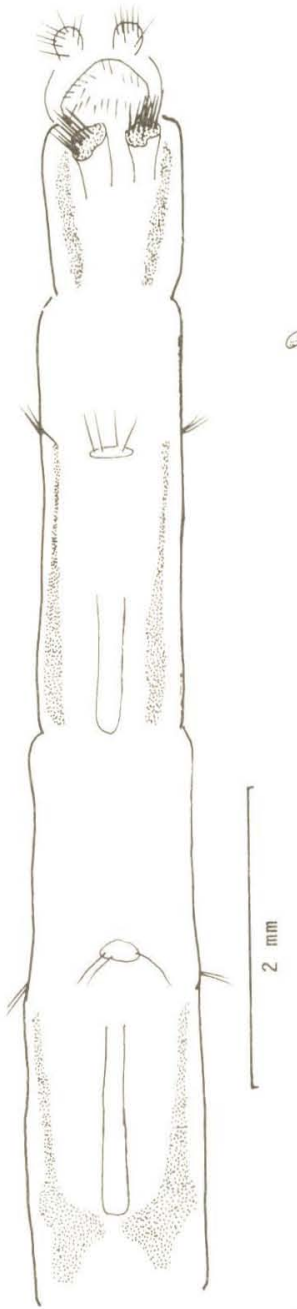

27

FIGS. 25-27. Ovipositores, vista ventral: 25, Palpibracus nigriventris; 26, P. peruvianus, comb. n.;27, P. reynoldsi. 
Revta bras. Zool.


32

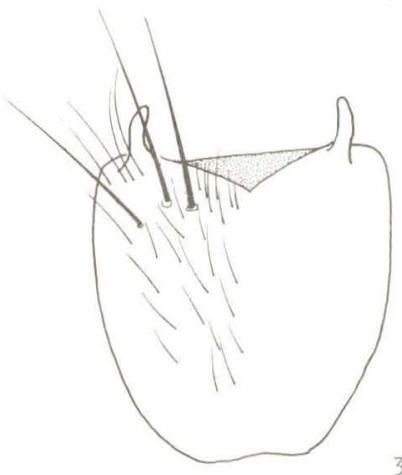

33
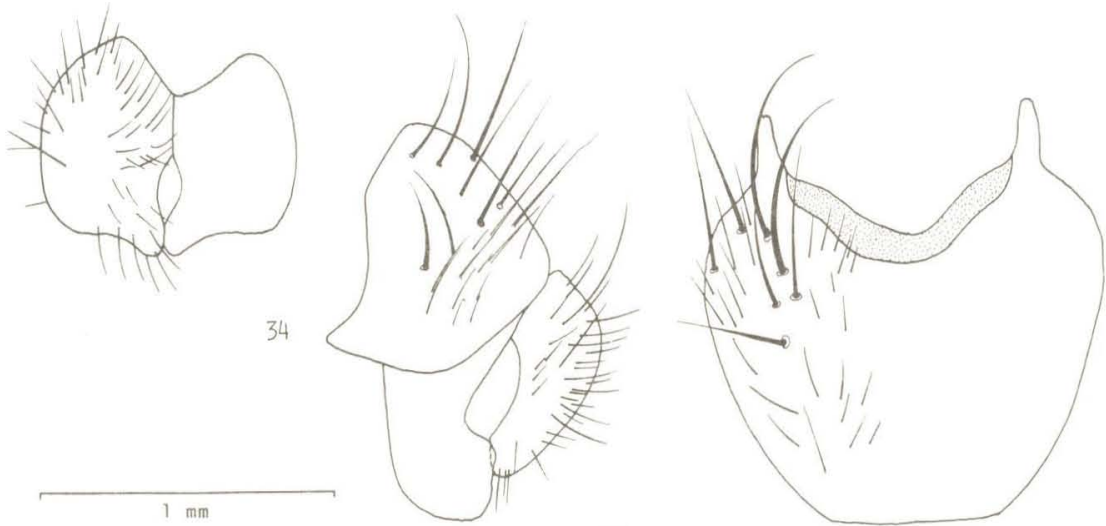

35

36

FIGS. 28-36. Palpibracus nigriventris: 28, cercos, vista posterior; 29, cercos, epândrio e surstilos, vista lateral; 30 , quinto esternito, vista posterior. P. peruvianus comb. n.: 31 , cercos, vista posterior; 32 , cercos, epândrio e surstilos, vista lateral; 33, quinto esternito, vista posterior. P. reynoldsi: 34 , cercos, vista posterior; 35 , cercos, epândrio e surstilos, vista lateral; 36 , quinto esternito, vista posterior. 
Vol. 6(2), 1989
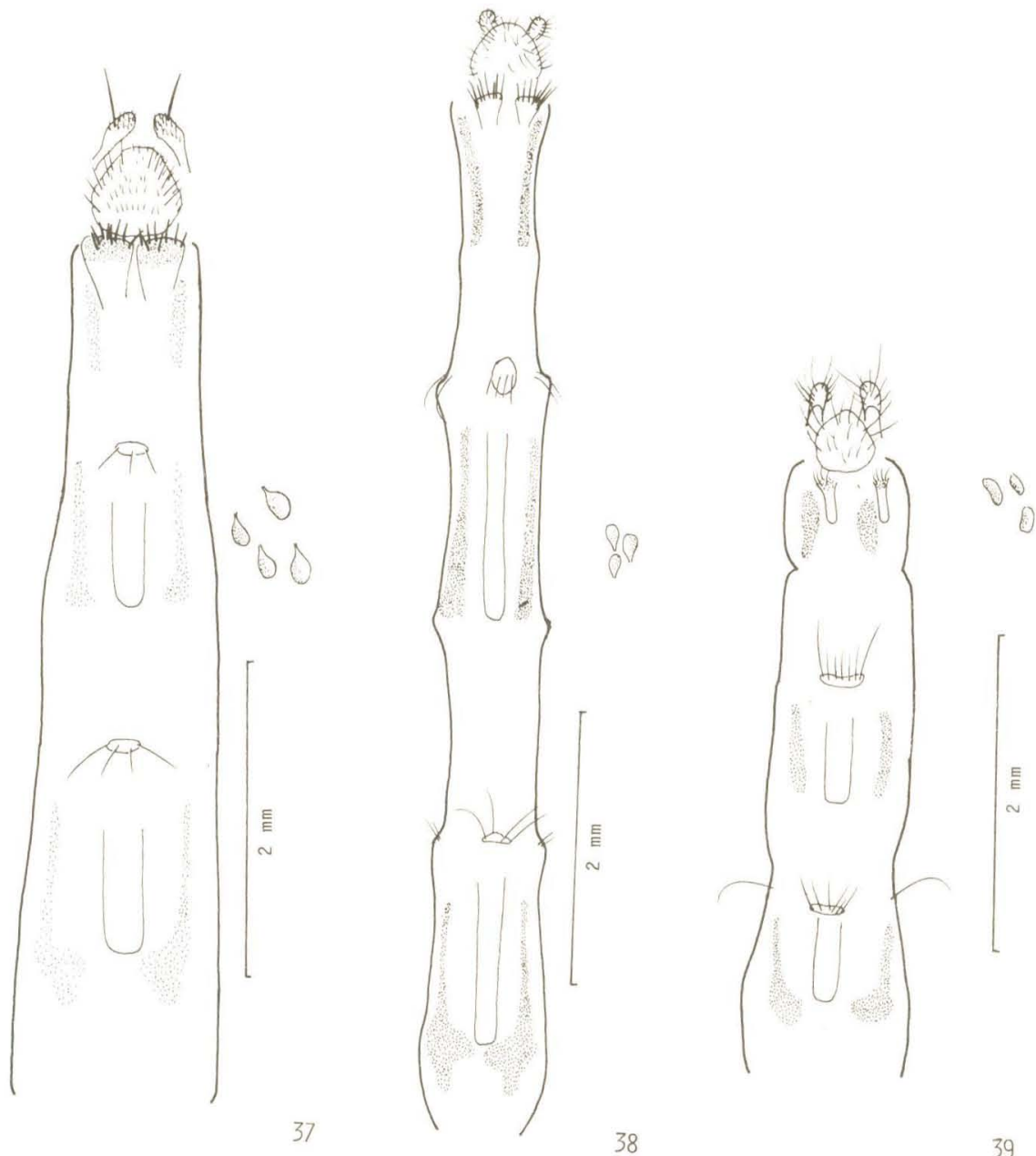

39

FIGS. 37-39. Ovipositores, vista ventral: 37, Palpibracus separatus; 38, P. similis; 39 , P. spicatus. 
Revta bras. Zool.

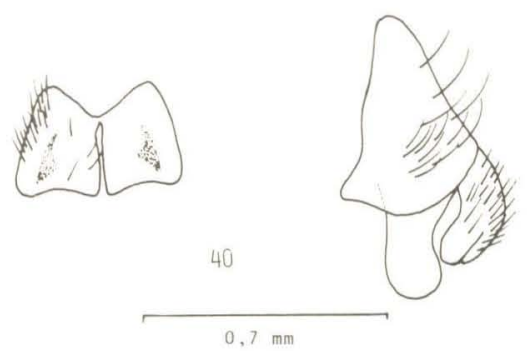

41
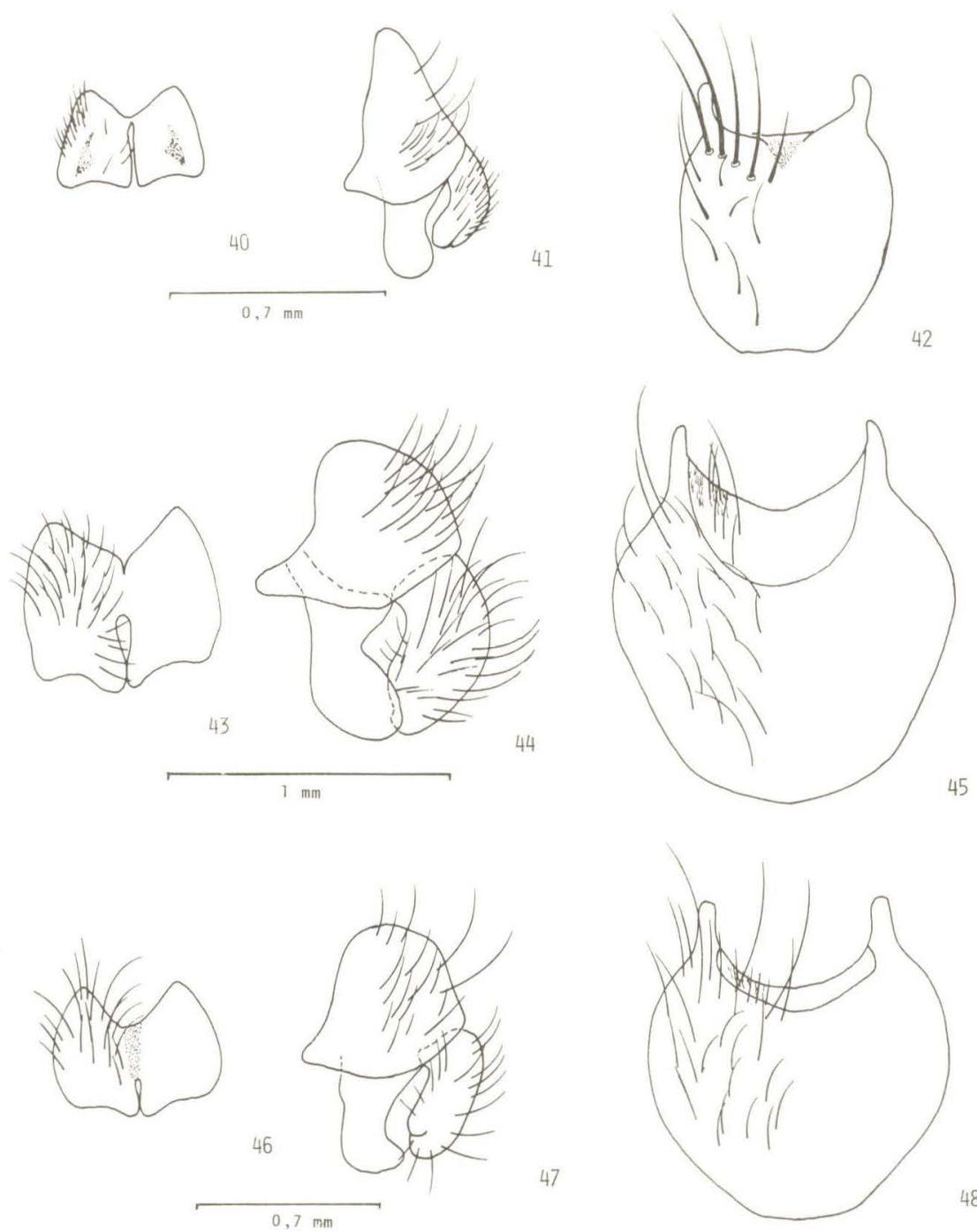

FIGS. 40-48. Palpibracus separatus: 40, cercos, vista posterior; 41, cercos, epândrio e surstilos, vista lateral; 42, quinto esternito, vista posterior. P. similis: 43 , cercos, vista posterior; 44, cercos, epândrio e surstilos, vista lateral; 45, quinto esternito, vista posterior. P. spicatus: 46 , cercos, vista posterior; 47 , cercos, epândrio e surstilos, vista lateral; 48 , quinto esternito, vista posterior. 
Vol. 6(2), 1989
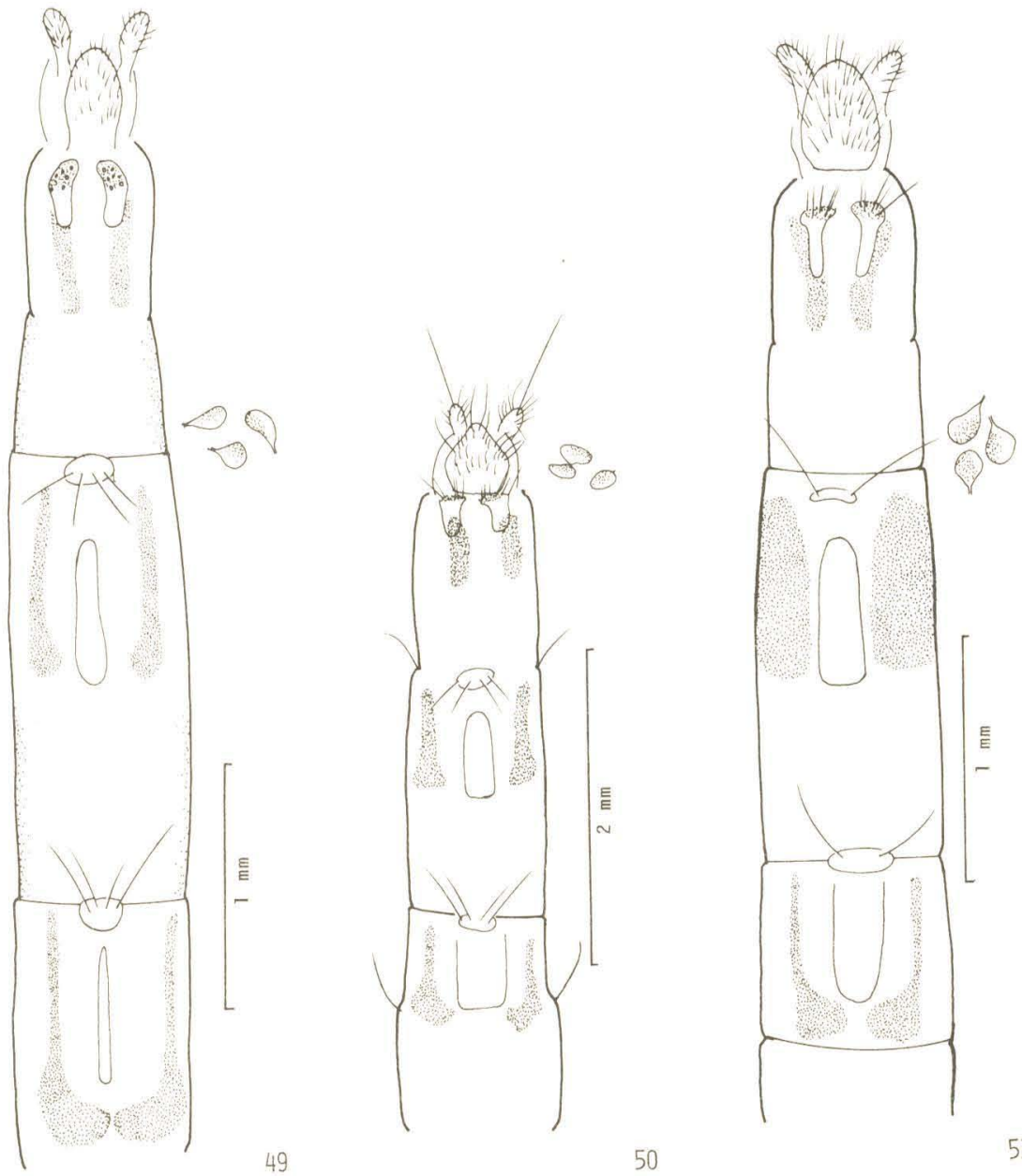

FIGS. 49-51. Ovipositores, vista ventral: 49, Palpibracus trivittatus; 50, P. univittatus; 51 , P. veneris. 

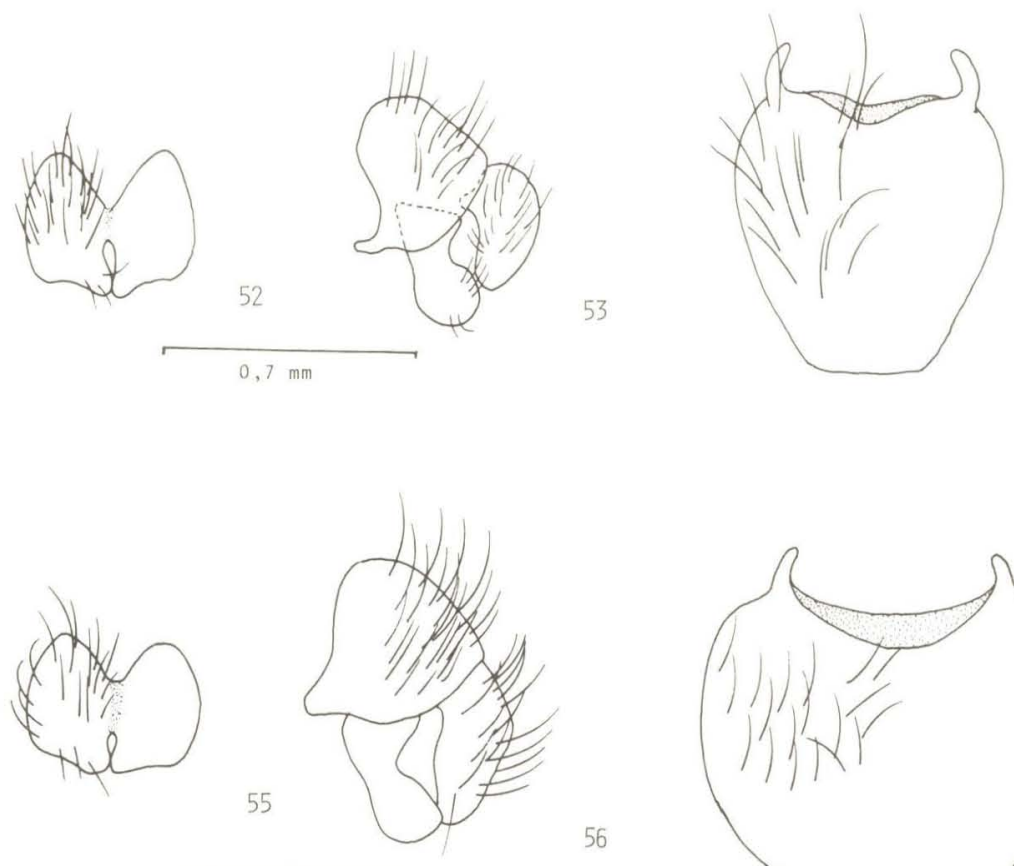

$0,7 \mathrm{~mm}$

56

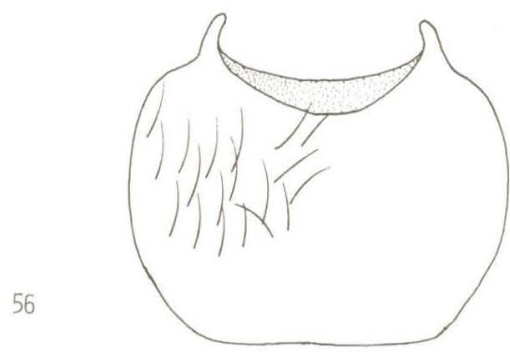

57

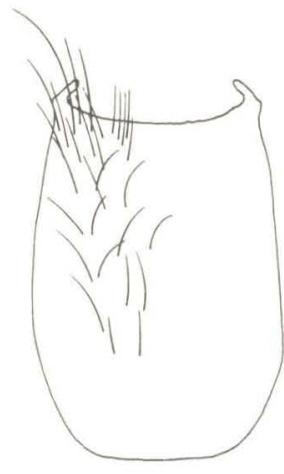

FIGS. 52-60. Palpibracus trivittatus: 52, cercos, vista posterior; 53, cercos, epândrio e surstilos, vista lateral; 54, quin to esternito, vista posterior. P. univittatus: 55 , cercos, vista posterior; 56, cercos, epândrio e surstilos, vista lateral; 57, quinto esternito, vista posterior. P. veneris: 58 , cercos, vista posterior; 59 , cercos, epândrio e surstilos, vista lateral; 60 , quinto esternito, vista posterior. 
Vol. 6(2), 1989

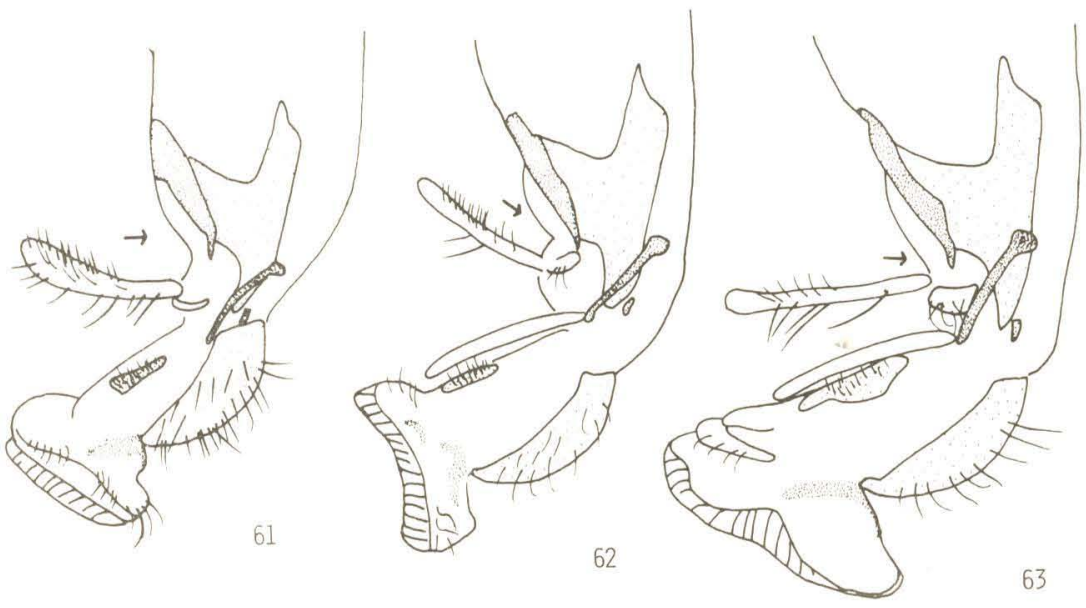

63

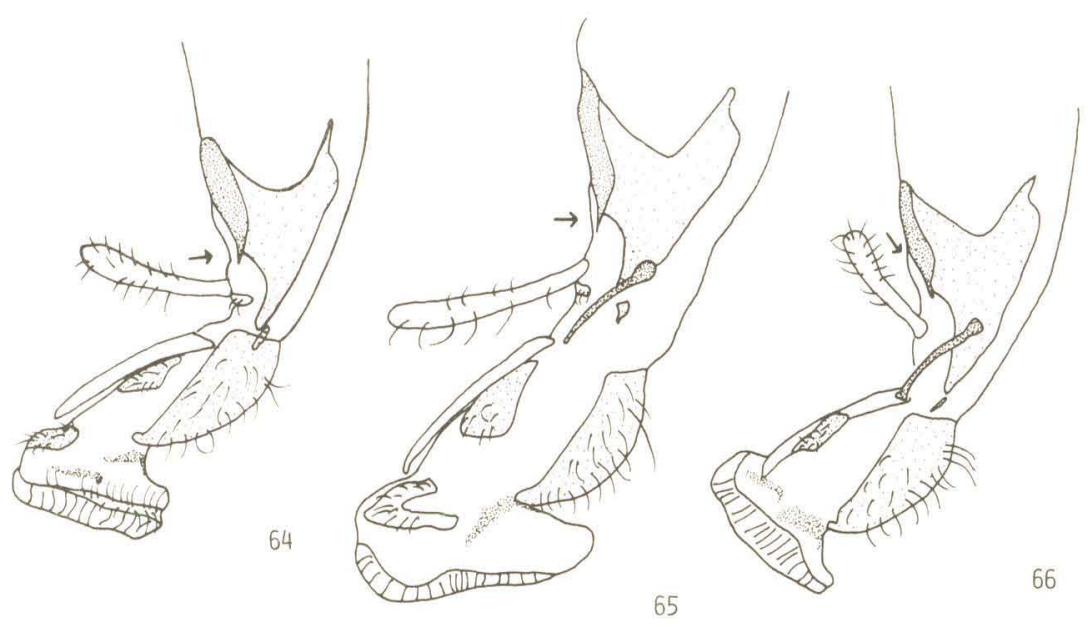

FIGS. 61-66. Probóscide, vista lateral, fêmea: 61, Palpibracus apicalis; 62, P. confusus; 63 , P. chilensis; 64, P. fasciculatus; 65 , P. lancifer; 66, P. nigriventris. 

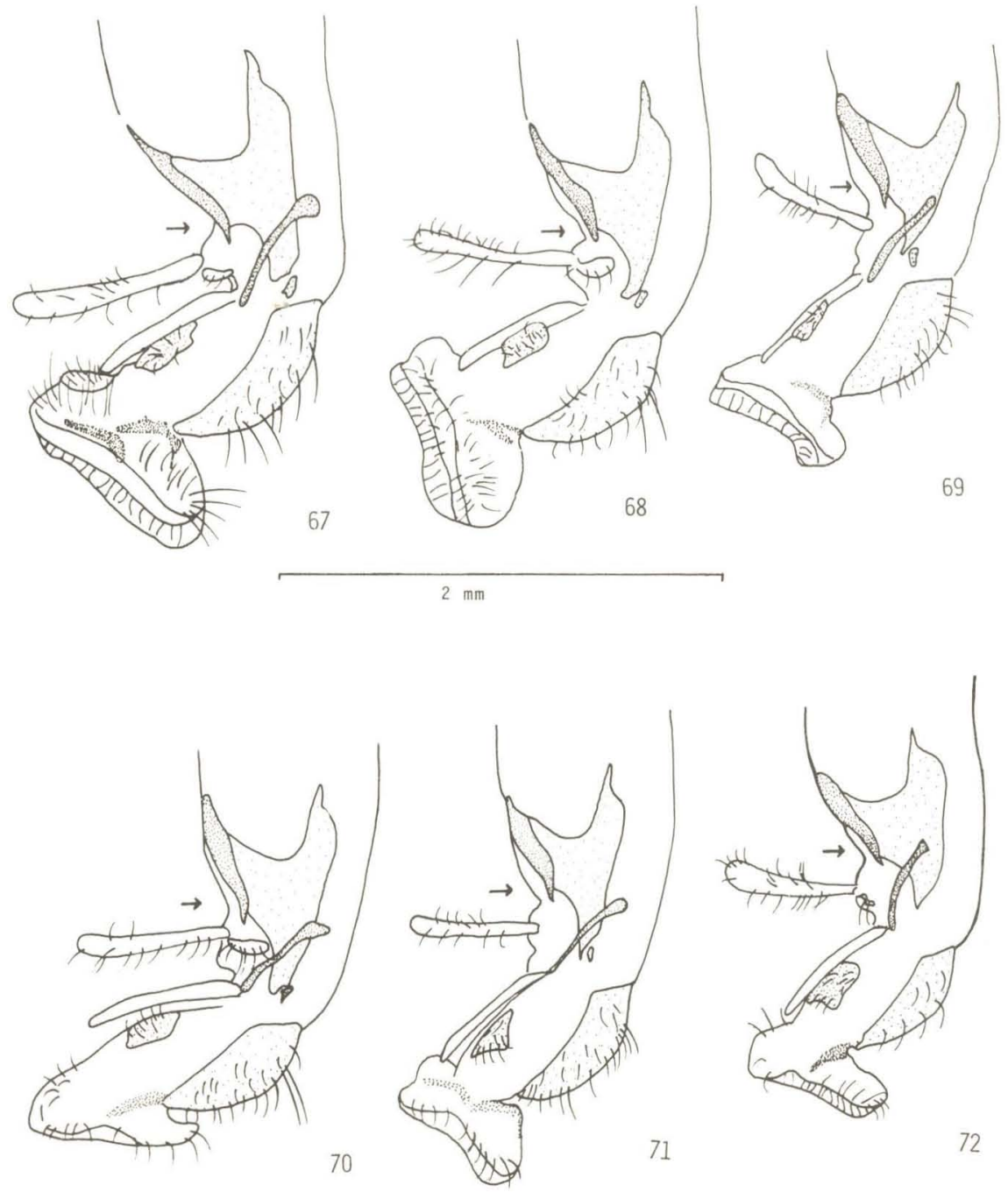

FIGS. 67-72. Probóscide, vista lateral, fêmea: 67, Palpibracus reynoldsi; 68, P. separatus; 69, P. spicatus; 70, P. trivittatus; 71, P. univittatus; 72, P. veneris. 


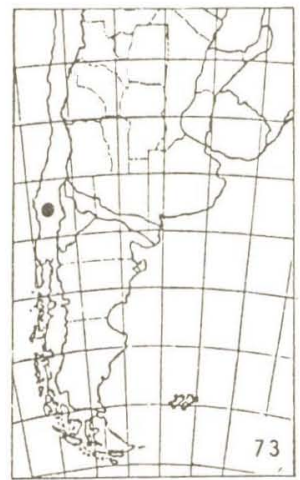

P. albuquerquei

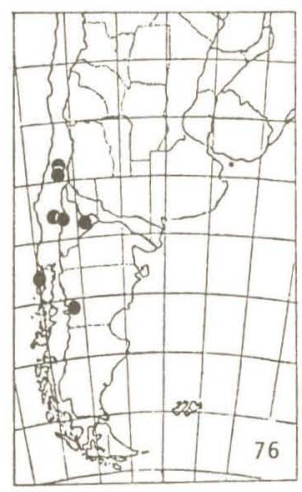

$P$. confusus

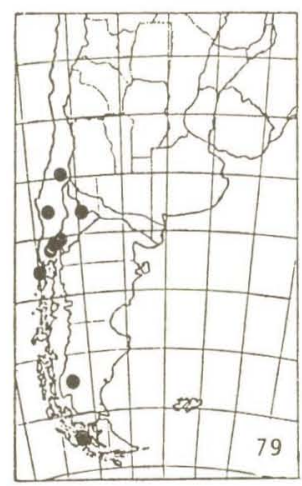

P. nigriventris

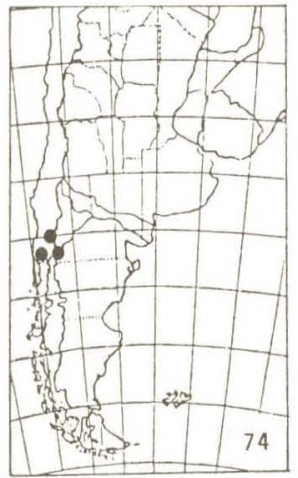

P. apicalis

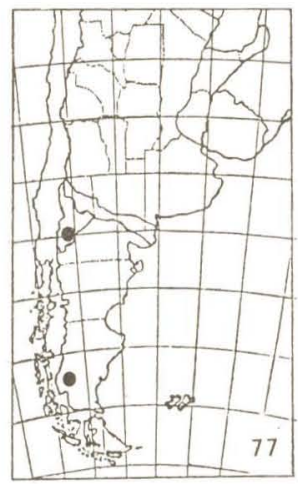

P. fasciculatus

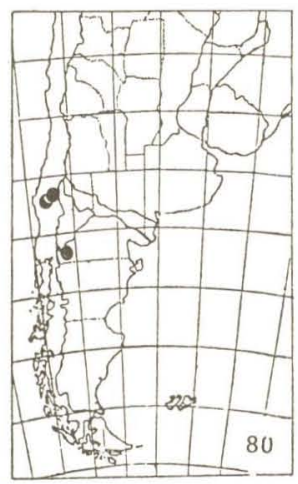

P. peruvianus

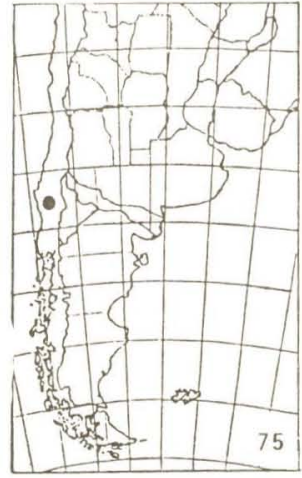

$P$. chilensis

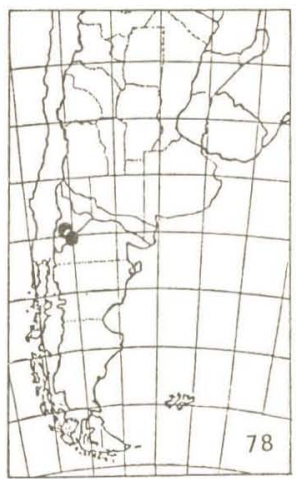

P. lancifer

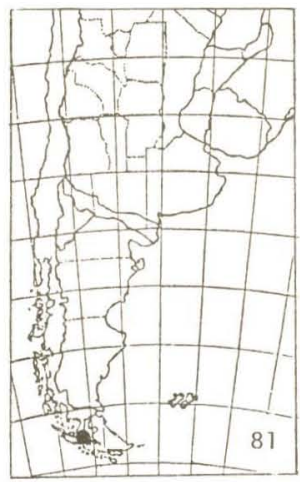

P. pilosus

FIGS. 73-81. Distribuição geográfica das espécies de Palpibracus. 
Revta bras. Zool.

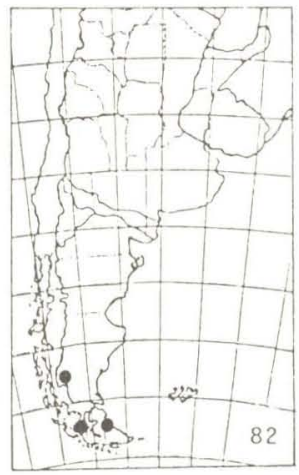

P. reynoldsi

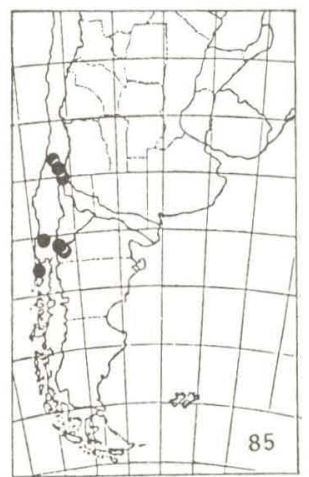

P. spicatus

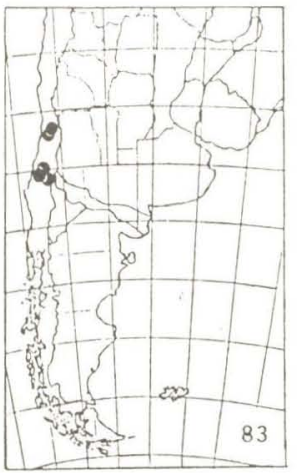

P. separatus

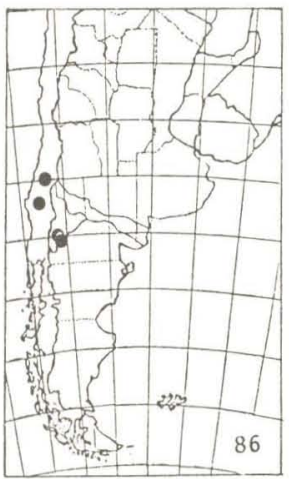

P. trivittatus

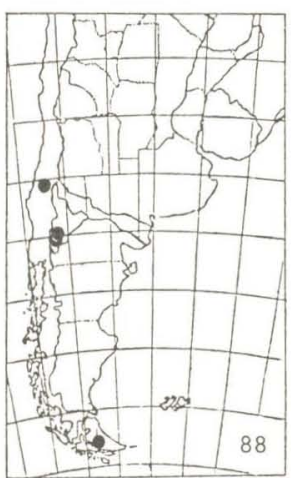

$P$. veneris

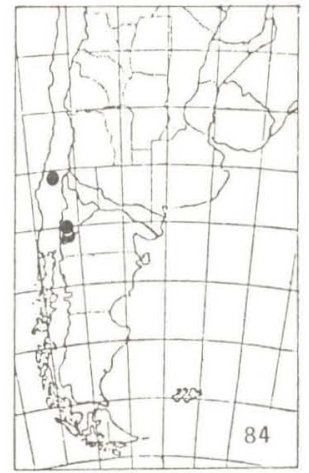

P. similis

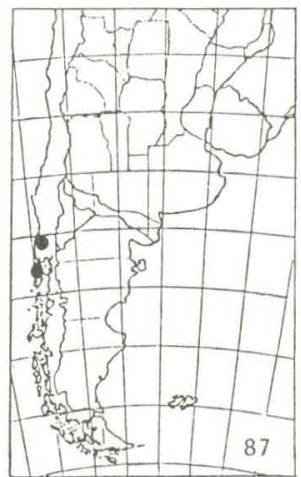

P. univittatus

FIGS. 82-88. Distribuição geográfica das espécies de Palpibracus. 


\section{REFERENCIAS}

ALBUQUERQUE, D. O. 1951. Quinta nota sobre os tipos de Macquart (Diptera-Muscidae), existentes no Museu Nacional de História Natural de Paris e descrição de uma espécie nova, proveniente do Chile. Bol. Mus. Nac. Rio de J., (n.s.) Zool., 105: 1-17.

ALBUQUERQUE, D. O. 1958. V. Contribuição ao conhecimento de Phaonia R. D., 1830, com descrição de novas espécies. Bol. Mus. Nac. Rio de J., (n. s.) Zool., 179: 1-38.

ALBUQUERQUE, D. O. 1979. Algumas notas sobre Muscidae neotropicais e descrição de um gênero e uma espécie nova (Diptera). Revta bras. Biol., 39 (2): 323-326.

ARNAUD, P. H. 1979. A catalog of the types of Diptera in the collections of the California Academy of Sciences. Myia, San Francisco 1:1-505.

BIGOT, J. - M. F. 1857. Dipteres nouveaux provenant du Chili. Ann. Soc. Entomol. Fr. 5 (3): $277-308$.

BIGOT, J. - M. F. 1885. Dipteres nouveaux ou peu connus. 250. partie. XXXIII. Anthomyzides nouvelles. Ann. Soc. Entomol. Fr. 4 (6) (1884): 263-304.

BIGOT, J. - M. F. 1888. Dipteres. In: Mission Scientifique du Cap Horn, 1882-1883. Paris, Tome VI, Zoologie, 2, 45 p.

CARVAlHO. C. J. B. 1983. Considerações sobre Phaonia Robineau-Desvoidy (Diptera, Muscidae) e descrições de novas espécies da Região Neotropical. Revta bras. Ent. 27 $(3 / 4): 243-257$.

CARVALHO, C. J, B. 1984. Descrição de novas espécies de Phaonia Robineau-Desvoidy (Diptera, Muscidae) do México. Revta bras. Ent. 28 (1): 1-9.

CARVALHO, C. J. B. 1985a. Descrição de Charadrella albuquerquei, sp. n. (Diptera, Muscidae, Cyrtoneur ininae) da Amazônia, Brasil e chave para as espécies do gênero. Revta bras. Ent. 29 (2): 379-381.

CARVALHO, C. J. B. 1985b. A new systematic position for Scenetes Malloch, 1936 with a description of the genitalia of $S$. cardini Malloch (Diptera, Muscidae). Revta bras. Ent. $29(3 / 4): 575-577$.

CARVAlHO, C. J. B. (no prelo). Classificação de Muscidae: uma proposta através da Análise cladistica. Revta bras. Zool.

COURI, M. S. \& LOPES, S. M. 1985. Neotropical genera of Coenosiinae - Nomenclatural notes and key to identification (Diptera, Muscidae). Revta bras. Biol. 45 (4): 585-595.

DODGE, H. R. 1967. Two new metallic species of Helina from Chile (Diptera, Muscidae). Proc. Entomol. Soc. Wash., 69 (3): 241-243.

ENDERLEIN, G. 1927. Dipterologische Studien. XVII. Konovia, 6: 50-56.

ENDERLEIN, G, 1935. Dipterologica, III. Sber. Ges. naturf. Freunde Berl. (1935): 235246.

HENNIG, W. 1965. Vorarbeiten zu einem phylogenetischen System der Muscidae (Diptera: Cyclorrhapha). Stuttg. Beitr. Naturk. 141: 100p. 
HUCKETT, H. C. \& J. R. VOCKEROTH 1987. Muscidae, p. 115-1131. In: Manual of Nearctic Diptera, vol. II. Otawa, Agriculture Canada, Research Branch, Monograph 28, $v i+675-1332$ p.

LOPES, S. M. R.; M. S. COURI; C. J. B. CARVALO \& D. M. PAMPLONA (no prelo). Notes on types of Muscidae, Anthomyiidae and Fanniidae described by Albuquerque. Arq. Mus. Nac., R. J.

MACQUART, J. 1851. Dipteres exotiques nouveaux ou peu connus. $4^{\circ}$. Supplement (part). Mem. Soc. Sci. Agric., Lille (1850):134-294.

MALLOCH, J. R. 1922. Exotic Muscaridae (Diptera), V. Ann. Mag. Nat. Hist. 9 (9):271280.

Malloch, J. R. 1928. Exotic Muscaridae (Diptera), XXII. Ann. Mag. Nat. Hist. 2 (10): 307-319.

MALLOCH, J. R. 1929. Exotic Muscaridae (Diptera), XXVIII. Ann. Mag. Nat. Hist. 4 (10): 322-341.

MALLOCH, J. R. 1934. Muscidae. In: Diptera of Patagonia and South Chile. London, Part 7 (2), p. $171-346$.

MATSUDA, R. 1965. Morphology and evolution of the insect head. Mem. Am. Entomol. Inst. 4:1-334.

McALPINE, J. R. 1981. Morphology and Terminology, p. 9-63: In: Manual of Nearctic Diptera, vol. 1. Otawa, Agriculture Canada, Research Branch, Monograph 27, vi +674 p.

O'HARA, J. E. 1982. Classification, phylogeny and zoogeography of the North American species of Siphona Meigen (Diptera: Tachinidae). Quaest. Entomol. 18 (1-4):261-380.

PONT, A. C. 1972. Family Muscidae. In: A Catalogue of the Diptera of the Americas South of the United States 97, 111 p., Museu de Zoologia, Universidade de São Paulo.

PONT, A. C. 1973. Studies on Australian Muscidae (Diptera). IV. A Revision of the subfamilies Muscinae and Stomoxyinae. Aust. J. Zool., Suppl. Ser., 21: 129-296.

RONDANI, C. 1864. Dipterorum species et genera aliqua ex otica revisa et annotata novis nonullis descriptis. Arch. Zool. Anat. Fis., Modena 3 (1863): 1-99.

RUIZ, E, C. 1926. Una Excursion Entomologica. Rev. Chil. Hist. Nat. (1926): 158-176.

SEGJY, E. 1937. Diptera, Family Muscidae. In: Wytsman, P., Genera Insectorum, Bruxeles, $205: 604$ p.

SKIDOMORE P. 1985. The biology of the Muscidae of the world. Dordrecht, Junk Publishers, $\mathrm{xiv}+550$.

SNYDER, F. 1957. Notes and Descriptions of some Neotropical Muscidae (Diptera). Bull. Am. Mus. Nat. Hist. 113 (6):437-490.

STEIN, P. 1907. Revision der Bigot'schen und einiger von Macquart beschriebenen aussereuropaeischen Anthomyiden (Dipt). Z. Syst. Hymenopt. Dipterol. 7: 209-217; 273-293.

ZINOVJEV, A. G. 1981. "On the classification of Palearctic flies of the genus Phaonia R. - D. (Diptera, Muscidae)". Entomol. Obozr. 60 (3): 686-698. 